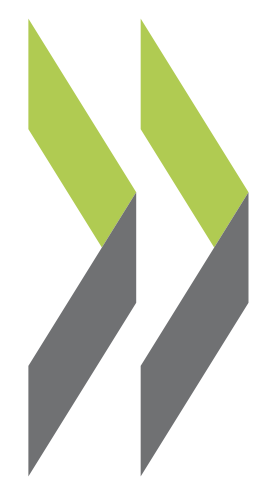

OECD Working Papers on Insurance and Private Pensions No. 7

\title{
Survey of Investment Choice by Pension Fund Members
}




\title{
\O
}

SURVEY OF INVESTMENT CHOICE BY PENSION FUND MEMBERS

\author{
E. Rozinka and W. Tapia
}

January 2007

OECD WORKING PAPER ON INSURANCE AND PRIVATE PENSIONS

No. 7

Financial Affairs Division, Directorate for Financial and Enterprise Affairs

Organisation for Economic Co-operation and Development

2 Rue André Pascal, Paris 75116, France

www.oecd.org/daf/fin 


\section{ABSTRACT/RÉSUMÉ \\ Survey of investment choice by pension fund members}

A recent trend in individual accounts schemes is the introduction and expansion of investment alternatives to plan members. The goal of investment choice is to enable plan members to select the optimal investment portfolio that matches their particular risk-return preference and ultimately, maximizes their retirement income. This document focuses on some key analytical and policy issues regarding investment choice by pension plan/fund members in occupational defined contribution and personal pension arrangements during the accumulation stage. The document covers the following selected OECD countries, Australia, Czech Republic, Hungary, Ireland, Italy, Mexico, Poland, Slovak Republic and Turkey. Furthermore, it covers some non-OECD countries such as Chile, Estonia, Hong Kong (China), Israel, Latvia, Peru, Russia and South Africa.

Classification JEL : G23

Keywords: Pension funds; portfolio preferences; individual choice; individual accounts; investment alternatives; pension plans; investment return; administration fees; investment limits.

$* * * * *$

\section{Aperçu d'élection d'investissement par les membres des fonds de retraite}

Une des nouvelles tendances dans les comptes de retraite individuelle est l'introduction et l'expansion d'alternatives d'investissement pour les membres des fonds. L'objectif de la sélection d'investissement est de permettre aux membres des fonds de retraite de choisir un portfolio d'investissement optimal en accord avec leur préférence au risque et qu'en fin de comptes maximise leur revenu au moment de la retraite. Ce document est centré sur des sujets clefs d'analyse et de politique à propos de la sélection d'investissement des membres des plans/fonds professionnels et individuels, pendant la période d'accumulation. Ce document couvre les pays membre de l'OCDE qui suivent : L'Australie, la République Tchèque, l'Hongrie, l'Irlande, l'Italie, le Mexique, la Pologne, la République Slovaque et la Turquie. De plus, il couvre certains pays non membres, tels que le Chili, l'Estonie, Hong Kong (Chine), l' Israel, la Letonie, le Pérou, la Russie et l'Afrique du Sud.

Classification JEL : G23

Mots clefs: Fond de retraite, préférences de portfolio; élection individuelle; comptes individuelles; alternatives d'investissement; plan de retraite; retours d'investissements; frais d'administration; limites d'investissement.

\section{Copyright OECD, 2007}

Applications for permission to reproduce or translate all, or part of, this material should be made to: Head of Publications Service, OECD, 2 rue André-Pascal, 75775 Paris Cédex 16, France. 


\title{
SURVEY OF INVESTMENT CHOICE BY PENSION FUND MEMBERS
}

\author{
E. Rozinka and W. Tapia ${ }^{1}$
}

\section{Introduction}

1. This background document focuses on some key analytical and policy issues regarding investment choice by pension plan/fund members in occupational defined contribution and personal pension arrangements during the accumulation stage.

2. The document covers the following selected OECD countries, Australia, Czech Republic, Hungary, Ireland, Italy, Mexico, Poland, Slovak Republic and Turkey. Furthermore, it covers some nonOECD countries such as Chile, Estonia, Hong Kong (China), Israel, Latvia, Peru, Russia and South Africa.

3. The paper is organized as follows: section I presents the pension plans covered by the survey. Section II provides a summary about issues on legal framework of member choice. Sections III and IV give a description about individual choice at three different levels: pension providers, product and portfolio choice. Section V shows the modalities for changing administering institutions, product and portfolio. Finally, in section VI, statistical information is presented.

\section{Pension plans covered by the survey}

4. The following table lists the pension plans in the selected countries covered in the survey. Most are personal pension plans, but in the case of Australia, Hong Kong (China), Ireland, Italy and Poland, occupational plans are also analysed. Both mandatory and voluntary plans are covered in several countries (such as Chile, Estonia, Hong Kong (China), Peru, Poland and Slovak Republic).

Table 1

\begin{tabular}{|l|l|}
\hline \multicolumn{1}{|c|}{ Country } & \multicolumn{1}{|c|}{$\begin{array}{c}\text { Pension plans covered by the survey } \\
\text { concerning member choice issues }\end{array}$} \\
\hline Australia & $\begin{array}{l}\text { Mandatory occupational DC, personal pension } \\
\text { plans (Retirement Savings Account). }\end{array}$ \\
\hline Chile & $\begin{array}{l}\text { Mandatory pension plan, Voluntary pension } \\
\text { plan. }\end{array}$ \\
\hline Czech Republic & $\begin{array}{l}\text { Personal pension plan (Supplementary pension } \\
\text { insurance) }\end{array}$ \\
\hline Estonia & $\begin{array}{l}\text { Individual mandatory funded pension plan (II } \\
\text { pillar), voluntary funded pension plan (III } \\
\text { pillar). }\end{array}$ \\
\hline
\end{tabular}

\footnotetext{
${ }^{1}$ The views expressed herein are those of the author and do not necessarily reflect those of the OECD or the
} governments of its Member countries. The author is sole responsible of any errors.

Contact information: Waldo Tapia, Private Pensions Unit, Financial Affairs Division, Directorate for Financial and Enterprise Affairs, Organisation for Economic Co-operation and Development, 2, rue André Pascal, Paris 75116, France. E-mail: fiona.stewart@oecd.org 


\begin{tabular}{|c|c|}
\hline Hong Kong (China) & $\begin{array}{l}\text { Mandatory occupational (MPF Schemes), } \\
\text { Voluntary occupational (ORSO Schemes) } \\
\text { pension plans. }\end{array}$ \\
\hline Hungary & Voluntary pension plan. \\
\hline Ireland & $\begin{array}{l}\text { Personal pension plan (Personal Retirement } \\
\text { Saving Account-PRSA), Occupational pension } \\
\text { plan. }\end{array}$ \\
\hline Israel & $\begin{array}{l}\text { Occupational defined contributions pension } \\
\text { plans and personal pension plans. }\end{array}$ \\
\hline Italy & $\begin{array}{l}\text { Occupational pension funds (closed and open } \\
\text { pension funds) }\end{array}$ \\
\hline Latvia & Mandatory pension plan. \\
\hline Mexico & Mandatory pension plan. \\
\hline Peru & $\begin{array}{l}\text { Mandatory pension plan, Voluntary pension } \\
\text { plan. }\end{array}$ \\
\hline Poland & $\begin{array}{l}\text { Mandatory personal (OFE), Voluntary } \\
\text { occupational (PPE), Voluntary personal (IKE) } \\
\text { pension plans. }\end{array}$ \\
\hline Russia & Funded mandatory pension plan. \\
\hline Slovak Republic & $\begin{array}{l}\text { Mandatory personal pension, Supplementary } \\
\text { voluntary personal pension plans. }\end{array}$ \\
\hline South Africa & $\begin{array}{l}\text { Voluntary occupational pension plan (retirement } \\
\text { fund). }\end{array}$ \\
\hline Turkey & Voluntary personal pension plan. \\
\hline
\end{tabular}

5. In Australia, besides the mandatory occupational DC, voluntary occupational DC and voluntary personal systems, there can be found a special saving account called RSA. These Retirement Savings Accounts (RSAs) are non-trust based superannuation accounts that are offered directly off the balance sheets of either life companies or Approved Deposit Taking Institutions (banks, credit unions, friendly societies). RSAs are governed by separate legislation (the Retirement Savings Account Act 1997). The liabilities represented by these accounts are liabilities of the institutions concerned.

6. In Chile, the privatized pension scheme was introduced in 1981. The new system consists of mandatory individual accounts managed by pension funds management companies (AFPs). The employer is not required to contribute. Participation is not mandatory for the self-employed. Additionally, workers may also make voluntary contributions to their accounts and may also set-up separate, voluntary saving accounts with others pensions institutions.

7. The voluntary pension scheme in the Czech Republic was created in 1994 by a legal Act (Act. $\mathrm{N}^{\circ}$ 42/1994 Coll.). Participation in the existing voluntary (supplementary) pension plans scheme is based on 
individual contracts. Everyone older than 18 years of age with permanent residence in the Czech Republic can become a member and participation has been encouraged through tax incentives and by a subsidy offered by the State to members' contributions.

8. When pension reform was started in 1998, Estonia opted for a three-pillar pension system. The funded pension is the main support to the state pension, providing supplementary income for pensioners. It is a retirement savings plan where a working person saves for his or her own pension. Subscription to the funded pension is mandatory for taxpayers born in 1983 or later. The funded pension is voluntary for those born before 1983 .

9. In Hong Kong (China), both the mandatory occupational DC plans (Mandatory Provident Fund, MPF Schemes) and voluntary occupational DC plans (Occupational Retirement Schemed Ordinance, ORSO Schemes) allow individual choice. ORSO Schemes can be further divided into two types, with the MPF exempted ORSO schemes and non-MPF exempted ORSO schemes. Employers of employees participating in MPF exempted ORSO schemes do not need to enrol those employees into an MPF Scheme and make contributions to such an MPF Scheme. In this sense, MPF exempted ORSO schemes can be said to contain some mandatory components.

10. The portfolio choice in Hungary can be found in the third pillar, (but it is available in case of only a few voluntary pension funds). The participation in this pillar is completely voluntary for both employees and employers. The voluntary pension funds are founded by a minimum of 15 persons.

11. In Ireland the system includes occupational pension schemes and personal pension plans. The PRSA is a new type of personal pension contract introduced in 2003. It is a contract between an individual and an authorised PRSA provider. The Pensions Board and the Revenue jointly approve PRSA products. The Board supervises the PRSA providers in relation to their approved products and the Financial Regulator is responsible for the prudential supervision of these providers.

12. In Israel, both occupational defined contributions pension plans and personal pension plans allow individual choice. The participation in the occupational pension plan is completely voluntary for both employees and employers.

13. The private pension system in Italy is represented by supplementary and voluntary funded pensions. The reformed system (laid down in 1993) is based on two options: closed (or contractual) pension funds regulated by collective agreements, and open funds managed by financial intermediaries that can be joined by workers individually or in groups ${ }^{2}$.

14. The Latvian pension system was introduced through a series of new measures but mainly through the pension reform adopted in 1995 which resembles the reformed Swedish model. The pension system is based on three main pillars. Individual choice currently exists in the second and third (voluntary and private) pillars. The second pillar is the State Funded Pension Scheme (SFPS). It is designed as a fully funded defined contribution mandatory scheme. The first stage of the second pillar was introduced on 1 July 2001 (with only one asset manager) and the second stage began operating on 1 January 2003 (with multiple private asset managers). Participation is mandatory for the age group under 30 at the moment of the Law taking effect, and voluntary for the age group between 30 and 49.

\footnotetext{
${ }^{2}$ According to the 2004 reform, the severance pay 'end-of-service allowance' (Trattamento di Fine rapporto - TFR, a portion of the worker's pay set aside by the employer and then paid as a lump sum at the end of employment) will be automatically transferred to the occupational pension fund, except the case the employee refuse it.
} 
15. The Mexican pension reform came into effect in 1997. The reform was designed on a multi-pillar approach, with a mandatory defined contribution fully-funded system with individual accounts, complemented with a publicly managed first pillar with a redistributive objective, and a third pillar consisting of voluntary saving. Unlike other pension reforms in Latin American countries, the option to continue contributing to a PAYG scheme has been completely eliminated, even for transitional workers.

16. The new defined-contribution pension scheme in Peru, was introduced as an alternative to the existing defined-benefit "pay-as-you-go" system, thus unlike similar reforms elsewhere in Latin America, every new cohort of entrants to formal employment in Peru since December 1992 is allowed to choose between a down-sized PAYGO, and a new branch of individual retirement accounts managed by "dedicated" (that is, specialized, single-service) private fund managers (AFPs). In addition, workers may also make voluntary contributions to their accounts.

17. In Poland, mandatory personal pension plans (OFE), established in 1999, have the form of open pension funds, obligatory to any person who became insured in the social security system and was born after 31 December 1968. Those born between 1 January 1949 and 31 December 1968 could have opted for open pension plans if they wished so. On the other hand, voluntary occupational pension plans (PPE) may be established since 1999. Despite (limited) fiscal stimuli they are not very popular among employers mainly due to their inflexibility and relatively high unemployment rate which makes this kind of additional staff motivation unnecessary. The relatively small popularity of this voluntary form of pension capital accumulation, as well as problems with transferring capital between PPEs or withdrawing it in case the new employer has not established any PPE, made the government propose a new form, voluntary personal pension plans (IKE). Finally, voluntary personal pension plans (IKE) may be established since September 2004. Although more popular than PPE, it is far below the Social Policy Ministry expectations. Insufficient fiscal stimuli are declared to be the most important barrier as far as IKE market further rapid development is concerned.

18. In Russia, the funded labour pension is a fully funded component of the mandatory pension system. It is accumulated with contributions to finance funded labour pensions payable by employers to the individual funded accounts of individuals at the Pension Fund of the Russian Federation or at a private pension fund (at the insured individual's choice). Contributions to finance funded labor pensions are made on behalf of those born in 1967 and after. Employers are required to remit 6 per cent of their wage bill to finance funded labour pensions ( 4 per cent as of now). Total contributions will make pension accumulations of an insured individual. These pension accumulations are pooled by the fund and passed to an independent asset manager of those selected on a tender basis. If the insured individual did not select an asset manager, his pension accumulations are passed to a public asset manager which makes conservative investments into a limited list of assets (primarily, government securities). As regards other asset managers, their investment of pension assets is subject to restrictions. The law established a list of eligible classes of assets and imposed restrictions on the structure and composition of investment portfolios. To the allowed extent, asset managers will draft an investment policy to be offered to insured individuals. Each insured individual has wide opportunities of choice within the funded pillar, for example, the right to annually select an asset manager for his pension savings from those selected on a tender basis, and the right to annually select a method of accumulating his funded labour pension (through the public pension fund or any private pension fund of those specially licensed to do so).

19. In the Slovak Republic, the establishment of capitalization second pillar came into force in January 2005. In this system of old-age pension saving, which has the nature of a compulsory defined contribution system, members pay monthly contributions to an individual account, which is managed by a pension asset management company (PAMC). The third pillar, additional pension saving, is administered by supplementary pension management companies (SPMC). This pillar is a fully funded defined 
contribution pension plan based on the principle of voluntary saving. The supplementary pension plans will start in 2006.

20. The personal pension plans in Turkey include individual savings (retirement) accounts operated on a DC basis. Employer contributions to these accounts on behalf of the employee are also possible and such plans are called Group personal pension plans. The collected funds in this system should be invested through investment vehicles called "pension mutual funds", which are mutual funds founded by the pension companies exclusively for the investment of pension monies.

21. In South Africa, the retirement fund provision is currently not compulsory but a tax incentive is granted to encourage employers (plan sponsors) to provide for retirement funding.

\section{Individual choices in pension plans covered by the survey}

22. Individual choice, including the choice of pension provider/administrator, product and investment portfolio, allows employees of pension plans to take into consideration their individual risk profiles and preferences. Appendix 2 presents a summarized picture about the examined countries. Australia is the only country where the mandatory pension system offers product choice. Product choice is available only in a few counrties (e.g. Estonia, Peru, Chile, Israel and Italy)., though further information on these systems is needed before drawing a clearer picture of the situation. It is also interesting to notice that in some countries, such as Australia, Hungary and South Africa, not all of the funds provide the option of investment portfolio choice for the members.

\section{Key issues regarding information on legal framework of member choice}

\section{Switching to a personal pension plan from occupational DC plans}

23. In Chile, Estonia, Hungary, Latvia, Slovakia and Peru there are no occupational pension plans. In Mexico and Turkey ${ }^{3}$ occupational pension plans are not regulated. In Hong Kong (China), the members can not opt out of the plan chosen by their employers.

24. In Chile, Estonia, Latvia, Mexico, Peru and Slovakia the members of a mandatory personal defined contribution pension plan are not allowed to switch to a supplementary personal defined contribution voluntary pension plan. Plan sponsors are not required to contribute to the voluntary pension plan chosen by the member.

25. Legislation permitting a choice of fund commenced in Australia on 1 July, 2005 for approximately half the employed workforce (those whose employment is subject to industrial awards or agreements under Commonwealth legislation). This means that these employees may direct their employer to pay their mandated employer contributions to a fund of their choice. Employees on state-based industrial arrangements will be able to choose the fund into which their mandated employer contributions are paid when proposed legislative changes take place. Amongst the range of funds to which a member can direct the employer to pay the mandatory contributions is a Self Managed Superannuation Fund.

26. In Ireland, if the terms and conditions of employment require the employee to be a member of the employer's plan, they will not be able to withdraw and switch to a personal pension plan. If there is no such contractual stipulation it is possible, but most unlikely, that a member could make such a switch. If the occupational plan does not offer a facility to members to make additional voluntary contributions (AVCs), the employer must provide access for the member to a Personal Retirement Savings Account (PRSA),

\footnotetext{
${ }^{3}$ The only private pension plans that are regulated and supervised by the pension regulator are the voluntary personal pension plans, the information provided below covers only such plans.
} 
which is a personal pension plan. The employer must deduct the member's PRSA contributions from their salary and remit these contributions to the PRSA provider. The employer does not have to contribute to the PRSA.

27. According to the new legislation in Italy, employees are able to choose between open and closed pension fund and individual pension plans (individual retirement arrangement). Closed or contractual pension funds, which are implemented either as company pension funds by a single company or as industry-wide pension funds set up by the employers' association and the trade union for a specific group of participants. Banks, insurance or investment companies offer open pension funds for a generic group of participant.

28. In Poland, switching from PPE (voluntary occupational pension plans) to OFE (Mandatory personal pension plans) is not allowed, but switching from PPE to IKE (voluntary personal pension plans) is possible. If any member of the staff decides to participate in IKE, he/she pays contributions on his/her own from his/her salary after social contribution and taxation deductions.

29. In Russia, this right is not available.

30. In South Africa, the Income Tax Act currently determines that all employees that are eligible to belong to the employer fund must belong to that fund. It is therefore compulsory where such a fund exists for employees to belong to the employer sponsored fund. Members will only have the option of another fund, where their employer is a participating employer of more than one fund and where the eligibility requirements would allow members to transfer to another fund. (Membership to a fund cannot be terminated unless employment has been terminated or the fund liquidated).

\section{Law/regulation related to requirement on return or benefit guarantees}

31. There are countries where the legislation does not require to managers to offer return or benefit guarantees: Hungary, Ireland, Israel, Italy, Mexico, Russia, South Africa and Turkey are such examples.

32. In Australia, mandatory occupational DC, Voluntary occupational DC and Voluntary personal systems do not guarantee a minimum return on contributions. However there is an account-based retirement savings product, called Retirement Savings Account ${ }^{4}$, which has the same features as a bank deposit by paying interest and there is a requirement in the legislation that they be capital guaranteed. Individuals may choose to have their superannuation contributions paid into such an account but there is no requirement that they be used.

33. In Chile, each AFP must guarantee that the average real return in the last 36 months is not lower than the lesser of (i) the average real return of each funds minus 2 percentage points for the funds $\mathrm{C}, \mathrm{D}$ and $\mathrm{E}$ (with a higher proportion of fixed income securities) and 4 percentage points for the funds $\mathrm{A}$ and $\mathrm{B}$ (with a higher equity exposure) or (ii) 50 per cent of the average real return of all the funds. If an AFP exceed the average rate by 2 percentage points (or by 4 percentage points) or 50 per cent (whichever is higher), the excess of return must be placed in a profitability fluctuation reserve, from which funds are drawn in the event the returns fall below the minimum return required. An AFP must also keep 1 per cent of the value of its pension funds as a separate cash reserve. These resources are used if the returns go below the lower boundry. When the difference is not covered by the reserve of the funds of the administrator, the authority must do it 5 .

\footnotetext{
${ }^{4}$ The Retirement Savings Account is an account based retirement savings product offered by banks and life insurance companies.

${ }^{5}$ See: Quantitative limits by asset class for each portfolio.
} 
34. In the Czech Republic, there is no minimum return guaranteed by law. However, the law requires that, if in any single year there are losses, they should be covered by the Reserve Fund", and "further funds created from profits". Thus, the plan members are protected against the risk of "negative profits", as long as the pension company does not become insolvent. This is equivalent to a guarantee to plan members that they will never have a negative (nominal) return.

35. In Estonia, pension funds cannot offer any investment return guarantees (neither individual mandatory funded pension - II pillar and nor the voluntary funded pension - III pillar). But insurance companies can offer certain products with guaranteed investment return (only III pillar).

36. In Hong Kong (China), neither the MPF schemes nor ORSO schemes have minimum return or benefit guarantees requirement.

37. According to the State-Funded Pension Law in Latvia, the state asset manager and the private asset mangers are not allowed to offer minimum investment return or benefit guarantees.

38. Since the inception of the new Mexican mandatory individual account system, no minimum guarantees are provided on the investment of the AFOREs, as it was felt that guarantees such as those required under other individual account systems, as Chile, and Peru, would unduly constrain the investment freedom.

39. Since the implementation of the Multifunds Law in Peru (November 2005) the guarantee of a minimum return for each of the funds managed by the AFPs, was replaced by a new system based on reference indexes of return or "benchmark". According to the new Law, each AFP must choose an index (benchmark) that reflects the composition and the expected return of the different categories of securities, bearing in mind the indexes must reasonably reflect the diversification and the risks included in the investment structure of each mandatory or voluntary fund. In addition, the indexes must reasonably reflect the performance of the market in which the security is traded.

40. In Poland, in the framework of OFE, a minimum required rate of return is to be attained. It equals 50 per cent of the market asset-weighed average or the market asset-weighed average minus 4 percentage points, whichever is lower. It is calculated every 6 months (last working days in March and September) on the 36-month performance basis. In the framework of PPE and IKE schemes, there are no guarantees unless otherwise stated in the contract.

41. Since the inception of the new investments scheme in Slovakia, the fund administrators are required to offer return guarantees by Law; regulations oblige PAMCs to guarantee a minimum return for each of their three funds ${ }^{7}$. At any moment upon the elapse of 24 months from the day when the pension management company started to create the pension fund, the minimum return is equal to the lower of two values: a) 90 per cent of the average yield during the past 24 months or the average yield minus 1 percentage points for the conservative pension fund, b) 70 per cent of the average yield during the past 24 months or the average yield minus 3 percentage points for the balanced pension fund, c) 50 per cent of the average yield during the past 24 months or the average yield minus 5 percentage points for the growth pension fund. In the case that a pension fund cannot hold this condition, PAMCs are obliged, within the term of five days from the violation of this condition, to transfer the assets from its own property to the property of a pension fund managed. SPMCs, on the other hand, are not required by law to offer return or benefit guarantees.

6 The Reserve Fund is formed with 5\% of the pension company profits.

${ }^{7}$ See: Quantitative limits by asset class for each portfolio. 
Table 2

\begin{tabular}{|c|c|}
\hline Country & $\begin{array}{l}\text { Law/regulation related to requirement } \\
\text { on return or benefit guarantees }\end{array}$ \\
\hline Australia & Just in case of Retirement Savings Account. \\
\hline Chile & Yes. \\
\hline Czech Republic & No. \\
\hline Estonia & $\begin{array}{l}\text { No. Insurance companies (third pillar) can } \\
\text { offer certain products with guaranteed } \\
\text { investment returns. }\end{array}$ \\
\hline Hong Kong (China) & No. \\
\hline Hungary & No. \\
\hline Ireland & No. \\
\hline Israel & No. \\
\hline Italy & No. \\
\hline Latvia & No. \\
\hline Mexico & No. \\
\hline Peru & Yes. \\
\hline Poland & Just in the case of OFE. \\
\hline Russia & No. \\
\hline Slovak Republic & Yes. \\
\hline South Africa & No. \\
\hline Turkey & No. \\
\hline
\end{tabular}

\section{Pre-retirement distributions (withdrawals), loans offered to members}

42. In Australia, regulated superannuation funds must not offer loans to members or other ancillary benefits that are not retirement, permanent disability or death benefits. There are strict limits on preretirement withdrawals on grounds such as severe financial hardship or compassionate grounds, and a tax penalty for early withdrawal may apply. From 1 July 2005, individuals who have reached the age at which preserved benefits can be paid out upon retirement (age 55 for those born before 1 July 1960, rising to age 60 for those born after 30 June 1964) but are still working may request payment of a non-commutable 
income stream without retiring from the workforce. Not all funds will offer these 'transition to retirement' pension products.

43. In the Czech Republic the supplementary pension scheme does not allow pre-retirement distributions. Loans to members are not allowed either.

44. In Estonia, in the mandatory funded pension scheme (II pillar) it is not possible to obtain preretirement distributions. It is possible in the voluntary pension scheme (III pillar), but the withdrawals are then taxed by ordinary income tax.

45. In Hong Kong (China), within the framework of MPF Schemes, benefits derived from mandatory contributions may only be withdrawn on grounds of retirement after age 65, early retirement after age 60, death, total incapacity, permanent departure from Hong Kong (China) or a small balance (MPF account of no more than $\mathrm{HK} \$ 5,000$ and member does not intend to work in future). There are no tax penalties when withdrawing benefits derived from mandatory contributions on the above grounds. Benefits derived from mandatory contributions may not be charged, pledged or assigned. Withdrawal of benefits derived from voluntary contributions subject to scheme rules. Benefits derived from employer voluntary contributions received by members due to termination of employment may be taxable on a sliding scale.

46. As regards MPF exempted ORSO schemes in Hong Kong (China), some members have to preserve a certain portion of their benefits (roughly equivalent to the accumulated benefits derived from mandatory contributions in mandatory occupational DC plan) until retirement. These members can withdraw such benefits on grounds of retirement after age 65, early retirement after age 60, death, total incapacity or permanent departure from Hong Kong (China). As for non-MPF exempted ORSO schemes, the preservation requirement does not apply. Members will usually be entitled to benefits upon retirement, ceasing employment, death or total incapacity. Whether the ORSO schemes can offer loans to members depends on the governing rules of the plan. The benefits derived from employer's contributions received by members due to termination of employment may be taxable on a sliding scale. As mentioned above, membership to a fund can only be terminated and a withdrawal payment made where the employment of the employee (member) has terminated or the fund liquidated. Tax becomes payable where a withdrawal benefit is paid.

47. In Hungary, following the waiting period (at least 10 years) and within the accumulation period, the fund member shall, with respect to access to his individual retirement account, have the option to a) continue membership in the fund under the same conditions, b) continue membership in the fund and, once every three years, withdraw all or part of the funds in his individual retirement account before reaching retirement age, c) close his account and terminate membership, d) leave the funds in his individual retirement account without paying additional membership dues. Any fund member - following the waiting period or after reaching retirement age - may pledge not more than 50 per cent of the balance on his individual account as collateral security in a contract concluded with a credit institution, if at the same time authorizing the fund to make an entry in his individual retirement account as locked-up by the member's instruction. The lock-up shall take effect simultaneously with the statement issued by the fund concerning the lock-up executed by the member's instruction in the form of an entry on the member's individual retirement account. The lock-up may be lifted only if so instructed by the member, or by the beneficiary in the event of the member's death, or by the holder of the collateral security if the conditions set out in the loan contract are satisfied if able to provide proof of the elimination of the claim for which it was pledged. For other aspects on locking up funds by the member's instructions, the provisions on liens on claims or rights shall apply. If the credit institution lodges any claim against the member's locked-up funds it shall be treated as if the member had made a withdrawal from his individual retirement account. 
48. In Hungary, the pension fund by-laws (constitutions) contain the rules of member loans. If, in spite of being properly notified by the fund, a fund member fails to repay a member loan in accordance with the terms and conditions laid down in the by laws, the fund may deduct the overdue amount along with the related expenses from the retirement account of the member in question. Such overdue amounts shall be regarded as the member's taxable income, and it shall not qualify as a fund service. On the basis of the certificate issued when the person's retirement account was debited, this amount shall be subject to tax prepayments pursuant to the Personal Income Tax Act as well as the health-care contribution in the percentage defined in the Healthcare Contributions Act. Regarding the taxation in Hungary, if a voluntary mutual pension fund makes any payment (provides any valuable consideration) to a member after the lapse of the compulsory waiting period that is not regarded as pension plan benefits (supplementary pension), the taxable income shall be determined as per the following: the sums paid (provided) in the year when the compulsory waiting period ends and during the next year, not including the sums paid (provided) from the amount credited to the individual account as the return on hedged investments or valuation differentials (hereinafter referred to as "income") shall be reckoned in their entirety, and in the percentages indicated below in subsequent years: 90 per cent of the income paid (provided) in the second year, 80 per cent of the income paid (provided) in the third year, 70 per cent of the income paid (provided) in the fourth year, 60 per cent of the income paid (provided) in the fifth year, 50 per cent of the income paid (provided) in the sixth year, 40 per cent of the income paid (provided) in the seventh year, 30 per cent of the income paid (provided) in the eighth year, 20 per cent of the income paid (provided) in the ninth year, 10 per cent of the income paid (provided) in the tenth year. Any income paid (provided) after the tenth year following the compulsory waiting period need not be taken into consideration when determining taxable income.

49. In Ireland, pre- retirement withdrawals are not permitted unless the member is leaving service. If the member leaves with less than 2 years plan service, he can take a refund of his own contributions subject to 20 per cent tax. Plans cannot offer loans to members.

50. In Israel, both occupational and personal pension plans allow members to obtain pre-retirement distributions. Both of them can also offer loans to plan members. There are tax penalties for early withdrawals.

51. In Italy, loans offered to members are prohibited. The employees who have been members of a plan for at least 8 years may withdraw their accumulated capital at any age if that have medical expenses, purchase a first house for themselves or their children.

52. In Poland, within the framework of PPE and IKE, pre-retirement withdrawals are allowed, but there are tax penalties. Loans to members are not allowed.

53. In Russia, pre-retirement withdrawals from pension accounts are not allowed except by legal successors in the event of the death of the insured individual before reaching the normal pensionable age.

54. In the Slovakian mandatory pension plans, pre-retirement distributions (in the form of programmed withdrawal with life annuity or in the form of life annuity) are possible provided that the actual balance of the member's personal pension account corresponds to the amount required for payment of such a pension for life and that the member has completed at least 10 years of old-age pension saving. Offering loans or other ancillary benefits is forbidden. No tax penalties for early withdrawals are charged. In the case of voluntary pension plans, these do not allow its member to obtain pre-retirement distributions. In the case of early withdrawal member is given more than 80 per cent his actual balance of the member's personal pension account. Offering loans or other ancillary benefits is forbidden.

55. In South Africa, pre-retirement withdrawals are not possible. Tax will only become payable when the benefit is paid to the member. However, where benefits are transferred from a pension fund to a 
provident fund, tax will become payable on the transfer as pension contributions are pre-tax and provident fund contributions are after tax contributions by the member.

56. In Turkey, early withdrawals from the pension plans are permitted. However, such distributions are subject to a higher tax rate when compared to withdrawal upon retirement. That is, early withdrawals are taxed at a rate of 10 per cent or 15 per cent, depending on the member's age and the time spent in the plan, whereas distributions to the retiring members are taxed at the rate of 3.75 per cent. The plans cannot offer loans. However, some plans provide free ambulance services and free health consultancy to their members as additional benefits.

\section{The employer's contribution, the tax limits on the employer's and member's contribution}

57. In Australia, an employer must contribute a minimum of 9 per cent of an employee's annual earnings towards their superannuation. If an employee is eligible to choose the fund into which the 9 per cent must be paid, the employer is obliged to pay the contribution to that fund. The maximum tax deduction allowed on the employer's contributions is age-based. The maximum deductions allowed during 2005-2006 are as follows: aged under 35: $\$ 14,603$, aged between 35 and 49: $\$ 40,560$, and aged 50 and over: $\$ 100,587$. Deductions in respect of personal contributions are only permitted where the person is self-employed or substantially self-employed, or not employed. The maximum deduction permitted is limited to the lesser of (a) the first $\$ 5,000$ of contributions plus 75 per cent of contributions in excess of $\$ 5,000$, and (b) the taxpayer's age-based limit for the year, as set out above.

58. In Chile, in the mandatory pension system, members who are actually working have the obligation to make regular deposits. The law sets these deposits at 10 per cent of taxable monthly wages, with an upper limit of $60 \mathrm{UF}$ (USD 1,950 approx.). In the voluntary contributions, members may freely pay contributions of up to 50 UF (US\$1,650 approx.).

59. In the Czech Republic, contributions paid by employers can be reduced from their tax base up to 3 per cent of employee's annual wages. The employer can make contributions of up to 5 per cent. This contribution is not considered part of the member's income, both for income tax purpose and for the calculation of social security contributions. Additionally, the State subsidises the member contributions. The "State contribution" adds up to 50 per cent of the amount contributed by participants

60. In Estonia, the funded pension is the main support to the state pension, providing supplementary income for pensioners. It is a retirement savings plan where a working person saves for his or her own pension, contributing 2 per cent of their gross salary to the pension fund. The state contributes an additional 4 per cent, (indirectly from the social insurance contribution paid by employers). Thus, the employer cannot contribute to the II pillar pension funds (contributions are from social tax +2 per cent from salary). The employer can contribute to the III pillar pension funds, but these contributions are then income taxed.

61. In Hungary, an employer, under a contract concluded with the fund, can undertake to pay part or all of its employee's membership contributions (employer's contribution). The employer undertaking the commitment to pay the employer's contribution may not exclude from the employer's contribution any employee who has been in employment (including public employees and civil servants) for at least 6 months. The rate of the employer's contribution shall be identical in respect of each employee who is a fund member; that is, it shall be the same amount or the same percentage of the employee's earnings without prejudice to the fund selected by the employee. The employer shall be permitted to determine its contribution under different principles for each type of fund. Where contribution is determined as a percentage of wages, the employer may define the lowest and highest amount of contribution. 
62. In Hong Kong (China), in the framework of MPF Schemes, employers must make mandatory contributions for its employees to these plans. The amount of employer contributions are equal to 5 per cent of employee's income (subject to a maximum monthly income ceiling of HK\$20,000) For the employee, tax-deductible up to a maximum of HK\$12,000 a year; for the employer, tax-deductible up to the limit of 15 per cent of the employee's emoluments (all retirement scheme contributions combined). For MPF exempted ORSO schemes, the employer must make contributions for its employees to these plans. Employers' contributions are entitled to tax deductions of up to 15 per cent of employee's emoluments (all retirement scheme contributions combined). Employees can enjoy tax deductions of up to HK\$12,000 a year. For non-MPF exempted ORSO schemes, schemes rules govern the amount of employer contributions (if any). For the employee there are no tax advantages; for employer, tax-deductible up to the limit of 15 per cent of the employee's total emoluments (all retirement scheme contributions combined)

63. In Ireland, employers must contribute to occupational pension plans - a Revenue condition for the approval of a plan. While Revenue will not insist that there be a stated minimum level of employer contribution, it will require that such contributions be "meaningful" in the context of the establishment, operation and provision of benefits under a plan. Any ordinary annual contribution paid by an employer to a plan is allowed as a deduction for tax purposes. Employers do not have to contribute to PRSAs. Members' contributions to a plan are allowable as an expense in assessing their liability to tax. The maximum contribution rate (as a percentage of total pay) on which they can receive tax relief is as follows: under age 30 it is 15 per cent, age between 30-39 it is 20 per cent, age between 40-49 it is 25 per cent and finally in the case of age 50 or over it is 30 per cent. For tax relief purposes these contributions are limited to earnings up to a maximum of $€ 254,0000$ in any tax year.

64. In Israel, employers are required to contribute in the occupational pension plans to the extent that they have committed to participate in any such plan by terms of an employment contract or agreement. The basic tax limits are as follows: an employer may receive a tax deduction on contributions of up to 15.33 per cent of an employee's salary, so long as the monthly salary does not exceed €5000. Such contributions do not constitute taxable income of the employee. In addition, an employee may receive a tax credit equal to 35 per cent of his contributions, to the extent that such contributions do not exceed certain limits.

65. In Italy, employee and employer contribution depend on plan rules and there is no legal upper limit but they are generally within the maximum amount for which tax relief is granted. TFR accruals can be contributed without limit to private pension fund. The annual TFR accrual is 6.9 per cent of total salary and is wholly paid by the employer.

66. Affiliates of the Latvian second pillar do not have to pay additional contributions. The total 20 per cent contribution rate is divided between the first and second pillar. Contributions to the fully-funded pillar began on July 1, 2001. Initially, 2 percentage points of the social tax rate will go to individual accounts, to be administered by the Social Insurance Agency. The share of the social tax dedicated to the fully-funded system will rise to 4 per cent in 2007 and then gradually to 10 per cent by 2010 .

67. In Mexico, under the new pension system, the employer, employee and government together contribute 6.5 per cent of a worker's wages to an individual retirement account. Additionally, Legislators decided to establish an additional government contribution called the "Cuota Social" which represents 5.5 per cent of the minimum wage at the time the new system takes effect, in order to benefit low income workers. The taxable worker's wage has a limit of 25 minimum wages.

68. In Peru, the contribution rate payable by the workers is 10 per cent of their taxable monthly income, with an upper limit. In the voluntary contributions, members may freely pay contributions without limits. 
69. In Poland, only the employee is obliged to pay the contribution. Employers may not pay any contribution to OFE. For PPE, the employer is obliged to pay contributions to voluntary personal plan for its staff. It cannot exceed 7 per cent of the employee salary. Employees may declare additional contribution that supplements that of employer's. It cannot exceed three times the maximum amount to be paid to IKE i.e. $3 * 150 \%=450 \%$ of average monthly salary, which is now of about EUR 630 . In frame of IKE, it is only the employee who pays contributions. It cannot exceed 150 per cent of expected average monthly salary for the coming year as the Budgetary Act states it.

70. In Russia, mandatory pensions are financed by employers. The law provides for the right of employees to make contributions on their behalf on a voluntary basis. Rates of mandatory contributions are established only for employers.

71. In Slovakia, the new pension system ( $\left(2^{\text {nd }}\right.$ pillar $)$ obliges workers to invest 9 per cent of the 28.75 per cent payroll taxes in private pension funds. ${ }^{8}$. In the voluntary pension plans, the employer may contribute for its employees. Tax limits for/of employers on contribution for his employees is stated at the 3 per cent of the amount of the employee's salary.

72. In South Africa, retirement fund provision is currently voluntary and there is no compulsory contribution rate. In terms of the Income Tax Act, the deductibility of contributions is limited to 20 per cent for employers and 7.5 per cent for member contributions. This percentage is calculated on pensionable salary of the member.

73. In Turkey, the employee can deduct his/her contributions from his/her income tax base. The employer may contribute to the plan on behalf of its employees. Also, the employer contributions can be deducted from the corporate tax base by the employer. The total amount of total tax deduction (income tax + corporate tax deduction) cannot exceed the limit - minimum of 10 per cent of the employee's gross wage and the amount of the gross minimum wage in Turkey.

\section{Law/regulation for administration fees (that providers can charge)}

74. In Australia, there are no limits on fees. The focus is on disclosure of fees. There are also 'member protection' standards designed to prevent the erosion of small balances (less than AU $\$ 1,000$ ) by administration costs in excess of earnings.

75. In Estonia, the fees that a provider can charge are threefold: (i) Unit issue fee: as a percentage of the net asset value of issued units, occasionally charged (max 3 per cent). (ii)Unit redemption fee: as a percentage of the net asset value of redeemed units, occasionally charged (max 1 per cent). (iii) Management fee: as a percentage of the market value of the assets of the pension fund, daily charged (max 2 per cent).

76. In Chile, for the services they provide, AFPs may charge a fixed monthly commission and a variable commission expressed as a percentage of the workers taxable income. The latter one includes the premiums for the term life and disability insurance the AFPs take out on behalf of their members. In order to ease the transition to the multifunds system, the commission structure and its standard application for all members have been maintained, regardless of the Fund which they may choose. By October 2005, the variable were equal to around 2.4 per cent of a taxable wage (including the cost of the disability and survivorship insurance), and the fixed commission of around 550 Chilean pesos (US\$ 1.02). At present, no Administrator is charging commission for managing the Voluntary Saving Account.

\footnotetext{
${ }^{8}$ The new pension system in Slovakia is voluntary for those who are already in the labour force and mandatory for new hires. The current workers may decide until June 2006 whether to begin saving on their individual pension accounts or stay in the reformed PAYG pillar.
} 
77. In Hong Kong (China), in the framework of MPF Schemes, there are certain fee restrictions in capital preservation funds. However, fees can be charged for the normal bid and offer spread of the fund options. There are no restrictions on fee structure and fee level. The regulatory focus is on clear disclosure of fees rather than restriction on fees. In frame of ORSO Schemes, there is no restriction either.

78. In Hungary, the fees that providers may charge are in connection with the admission to, exit from and switch of Pension Funds. There is a regular fee charged in every month, which is regulated by the bylaws of the Pension Funds, and are set in the percentage of the contribution paid by the member. Also fees are charged for asset management, according to the asset management contracts.

79. In Ireland, fees are only specified in relation to PRSAs. It provides that for Standard PRSAs a maximum charge of 5 per cent on the contributions paid and 1 per cent on the assets under management.

80. In Israel, the fees (type, structure and level) on the pension plans are determined in terms of the rules of the fund.

81. In Italy, there are no legal rules on fees charged by private pension providers. However, fees are established as a percentage of the net asset value (NAV).

82. In Latvia, the regulation states that the asset management companies of the State-funded Pension Scheme are allowed to charge fees only for a custodian bank and asset management ${ }^{9}$. The fee is established as a percentage of average annual assets of the investment plan. The asset management company can charge fees according to the investment plan or prospectus of a particular investment plan. Neither front load (entry), nor back load (exit) fees are allowed in the SFPC.

83. The Supervisor Authority in Mexico authorizes each Administrator to freely set management fees based on a percentage of contributions (a front-end fee), a percentage of assets under management, a performance-based fee or some combination of them.

84. In South Africa, currently there is no regulation of fees charged by administrators.

85. Initially (1993), the AFPs in Peru were allowed to charge affiliates three different types of commissions for the administration of pension funds: (i) a monthly fixed commission per affiliate; (ii) a monthly variable commission calculated as a percentage of the pensionable salary; and (iii) a monthly variable commission calculated as a percentage of the balances administered. However, since January 1997, the law allows only the variable commission as a percentage of contributions. Fixed fees on monthly contributions as well as variable fees charged on the balance of the affiliates have been prohibited.

86. In Poland, in the framework of OFE, the entry fee is according to the statute but no more than 7 per cent. The ongoing fee is according to a decreasing scale, up to 0,045 per cent per month. An additional high performance payment up to 0,005 per cent per month is also possible under certain conditions. Both in PPE and IKE plans, the fees are according to the statute and/or the contract.

87. In Russia, the annual asset management costs, including services of the specialised depository (custodian) cannot exceed $1.1 \%$ of the annual average value of net assets under management. Moreover, it is envisaged that the amount of remuneration of the asset manager will decrease as the value of assets under management grows.

\footnotetext{
${ }^{9}$ The custodian bank (based on agreement with the asset management company) holds assets of an investment plan and execute orders of the asset manager on the operations with these assets.
} 
88. In Slovakia, each PAMC may charge fees for managing the pension fund and for maintaining personal pension accounts. The management fee can vary from 0 up to $0.07 \%$ of monthly assets for each fund managed by the same PAMC. Only the upper limit of the management fee is stipulated by the law, therefore each PAMC can decide upon the amount of this fee. Remuneration of PAMC for maintaining personal pension account amounts to $1 \%$ of the amount of a monthly contribution for all types of funds. Regarding voluntary pension plan, SPMC is entitled to remuneration for managing the pension fund, to remuneration for switching between funds and for exit fees. Yearly remuneration for managing the pension fund may not exceed 3\% of assets of the pension fund. Exit fee may not exceed $20 \%$ of the balance of a personal account.

89. In Turkey, the legislation prescribes the fees, their structure, and also caps their level. According to the laws and regulations there are 4 different types of fees that providers can charge. The characteristics of each are as follows: (i) Entry fee for new entrants: These fees are not linked to the contributions, assets or performance. These fees are subject to a maximum, which is the monthly gross minimum wage in Turkey. The providers may collect these fees in 3 different ways. The first way is to collect them directly upon entrance, the second way is to collect them in the form of instalments within a year, and the third way is to defer the collection of these fees until the member leaves the plan. Most of the providers that choose the third option grants a waiver of this fee if the member stays within the plan for a certain period of time. (ii) Administrative fees on the contributions paid: The maximum fee that can be charged is limited to 8 per cent of each contribution. Some pension companies utilize a scale in which the percentage of these fees goes down as the amount of contribution increases. (iii) Fund management fees on the amount of total assets: The maximum limit, on a daily basis, for such fees is $10 / 100.000$ of the amount of total accumulation in the member's individual retirement account. The annual rate for this fee corresponds to approximately 3.72 per cent. (iv) Extra Services Fees: If the pension company provides extra services (such as sending info. frequently by SMS about the retirement account, etc.), a fee can be charged for such services. There is no cap stated by the law for such fees, so these fees are charged according to the personal pension contract between the pension company and the member.

Table 3

\begin{tabular}{|l|l|l|l|}
\hline \multicolumn{1}{|c|}{ Country } & Fees on contributions & \multicolumn{1}{|c|}{$\begin{array}{c}\text { Fees on accumulated } \\
\text { assets }\end{array}$} & Fees paid occasionally \\
\hline Australia & Up-front fee. & Management fee. & Switching fee. \\
\hline Chile & Up-front fee. & n/a. & Switching fee. \\
\hline Czech Republic & n/d. & n/d. & n/d. \\
\hline Estonia & Unit issue fee. & Management fee. & Unit redemption fee. \\
\hline Hong Kong (China) & n/a. & n/a. & n/a. \\
\hline Hungary & Operating fee. & n/a. & Entry fee, switching fee. \\
\hline Ireland & Charge on contributions. & Management fee. & n/a. \\
\hline
\end{tabular}




\begin{tabular}{|l|l|l|l|}
\hline Israel & n/a. & n/a. & n/a. \\
\hline Italy & n/a & Management fee. & n/a \\
\hline Latvia & n/a. & Management fee. & n/a. \\
\hline Mexico & Up-front fee. & n/a. & Switching fee. \\
\hline Peru & Up-front fee. & n/a. & Switching fee. \\
\hline Poland & Up-front fee. & Management fee. & Entry fee, exit fee. \\
\hline Russia & n/d & Management fee. & Switching fee may be set. \\
\hline Slovak Republic & Up-front fee. & Management fee. & Exit fee. \\
\hline South Africa & n/a. & n/a. & n/a. \\
\hline Turkey & $\begin{array}{l}\text { Administrative fee on } \\
\text { contributions. }\end{array}$ & Management fee. & Entry fee, extra service fee. \\
\hline
\end{tabular}

\section{Key issues regarding on choice of administering entity}

\section{Pension administrator institutions}

90. In Australia, pension plans are mostly structured as a trust fund, operated by a trustee company (or in some cases a group of individual trustees). The trustee entity is the sole responsible entity, although it may (and generally does) delegate functions such as administration and investment to a specialized service provider (which could be a life insurance company). Outsourcing of material business activities and functions must be subject to binding agreements between the trustee and the service provider and meet prescribed conditions. The trustees of superannuation funds must be licensed by the prudential regulator, and the funds must be registered by the regulator. There is no restriction as to the type of institution that may be licensed, provided all requirements are met (for example, capital for retail fund trustees, fit and proper, adequate resources, risk management $)^{10}$. Not all funds provide pension benefits. Many of the retail funds are sponsored by banking and life insurance conglomerates. There is no limit on the number of funds (administrator institutions) from which members may choose. Traditionally, as members have changed employment they have changed funds, which mean that many members have multiple accounts, many of which are small and costly to administer.

91. In the case of occupational DC plans in Australia, the choices open to the plan sponsor are i) to establish a fund with an equal representation trustee structure and to provide the administrative services itself or engage a third party administrator, and have the trustee entity perform the investment services or outsource to an investment manager, or ii) to establish the fund and have the trustee enter a contract with (invest in a policy of) a life insurance company for administration and investment services. Over recent

\footnotetext{
${ }^{10}$ It is important to note that a trustee must either be a constitutional corporation or a group of individual trustees. A licensee holding a public offer or extended public offer licence must be a constitutional corporation.
} 
years in Australia many occupational funds (both DB and DC) have been wound up or transferred to a master trust, or the former sponsor has elected to pay the mandatory employer contributions to a multiemployer sponsored industry fund.

92. In Chile, the mandatory private pension system is administered by single-purpose private institutions know as Pension Fund Administrator (AFPs). The AFPs and the retirement funds they administer are two completely separate legal entities, so that if an AFP goes bankrupt, the retirement fund is not affected. There is free entry and exit into the industry, even for foreign companies, provided that certain capital requirements are met. AFPs are required to maintain a legal reserve, a cash reserve, and a profitability reserve. In addition, they are required to provide at least one statement of account every four months to their customers free of charge. Regarding the voluntary contributions, from March 2002, the Law extend the number of institutions allowed to handle it, including Banks, mutual funds, insurance companies, housing fund managers and others authorized by the Superintendence of Securities and Insurance.

93. In the Czech Republic participation in the existing voluntary (supplementary) pension plans scheme is through pension companies. These are joint stock companies, incorporated in the Czech Republic under the provisions of the Commercial Code. The purpose of pension companies is limited to the provision of supplementary pension insurance. Pension companies must be licensed by the Ministry of Finance (in agreement with the Ministry of Labour and Social Affairs and the Securities Commissi In the beginning of the new pension scheme until the end of 2002, the only entity allow to manage the pension fund assets was the State Treasury, however from January 2003, members have been allowed to choose between the state asset manager and private administrators. on). Currently, there are 13 firms participating in the market.

94. In Estonia, pension fund manager companies must manage the II and III pillar pension funds (contribution period). The management company in the mandatory pension system may provide only the following services: (i) management of a securities portfolio; (ii) provision of advice upon investment; (iii) safekeeping of the members' individual accounts. By 2005, there are six pension fund management companies collecting mandatory contributions. Insurance companies can offer III pillar pension insurance (contribution period). There is no limit for number of pension funds or insurance companies. Pension payments can only be done through life insurance companies (annuities).

95. In Hong Kong (China), each MPF scheme must be managed by a trustee authorized by the Mandatory Provident Fund Schemes Authority (MPFA). The trustee can administer the contribution and benefits drawdown itself or it can appoint a third party administrator to do so. There is no restriction as to whom a third party administrator must be. It may be a pension fund administrator, a life insurance company, or others. Once a member withdraws benefits there are no restrictions on who can manage those funds whether they are taken as a lump sum or rolled into some annuity product. The choice of the trustee rests with the employer. Employees cannot choose the trustee. The ORSO schemes are sponsored by employers. Generally speaking, the employer would select the administering entity. There are no statutory requirements as to who can choose the administering entity and what kind of institution (e.g. bank, insurance company, etc.) an administering entity must be. However, for MPF exempted ORSO schemes, the plans must be managed by a trustee. The trustee can administer the contributions and benefits drawdown itself or it can appoint a third party administrator to do so. There is no restriction as to whom a third party administrator must be. It may be a pension fund administrator, a life insurance company, or others.

96. In Hungary there is no limitation in being an administering institution if the institution complies with the legislation in force. At present, there are only five funds from the 82 voluntary fund companies, which provide the portfolio choice for the fund members. 
97. In Ireland, the legislation defines who can act as a PRSA provider. The Pensions Board and the Revenue Commissioners jointly approve PRSA products. The Board supervises the activities of providers in relation to their approved products and the Financial Regulator is responsible for the prudential supervision of PRSA providers and the sales process of approved products. There are currently 10 PRSA providers with a range of 54 PRSA products. Employers who do not operate occupational plans must designate a PRSA provider to provide at least one Standard PRSA to their employees. As such, it is the employer who selects the PRSA provider. If the employees contribute to the Standard PRSA offered by that provider the employer must collect and remit the contributions on their behalf. If the employees do not favour the provider designated by the employer, they can choose an alternative provider from amongst the 10 approved providers but will have to make their own arrangements regarding payment of contributions i.e. the employer does not have to play a role. In the case of occupational pension plans in Ireland, it is the employer who will appoint the administering institution and the range of advisers involved with the plan i.e. lawyers, actuaries, accountants, investment managers.

98. In Israel, any institution can administer voluntary occupational defined contributions pension plans and voluntary personal pension plans except for banks and labour associations.

99. In the case of closed pension fund in Italy, the asset management must be contracted to an asset manager that may be a bank, insurance company, and investment firm or asset management company. An agreement must be signed between the government board of the pension fund and the asset manager. On the other side, the assets of the open pension funds are managed by a financial intermediary (banks, insurance companies or investment management companies) that is usually the institutions that established the fund.

100. In Latvia, only the state asset manager (State Treasury) and private pension fund managers are authorized to establish and administer the State-Funded Pension Scheme (second pillar). A private pension fund manager is a financial and credit joint stock company registered in the Commercial Register which in accordance with this Law and pension plans accumulates and invests contributions of monetary assets made by the pension plan participants themselves or voluntarily made in their favour in order to ensure an old age supplementary pension capital to such participants. In the beginning of the new pension scheme until the end of 2002, the only entity allow to manage the pension fund assets was the State Treasury, however from January 2003, members have been allowed to choose between the state asset manager and private administrators.

101. In Mexico, the pension funds are administered exclusively by investment management firms called AFORES, which may be established by private sector and trade unions. AFORES are single-purpose business corporations with independent capitalization. Each AFORE must maintain a minimum paid in capital and a special reserve as a percentage of the total assets. The establishment of AFORE require the authorization of the regulatory agency, which may grant or deny authorization at its own discretion after examining the business plan, shareholding, systems, control and management of the firm.

102. In Peru, the pension fund management companies are called Administradoras de Fondos de Pensiones (AFPs). These companies are not allowed to do any other business than pension fund management. They have to be set up as joint-stock companies. The retirement capital managed by an AFP is an independent entity, which is legally and financially separated from the companies' capital in order to ensure that members' assets are protected in case of an AFP's bankruptcy. AFPs must have a minimum capital requirement.

103. In Poland, in the framework of the OFE, only General Pension Societies (PTE) are allowed to administer OFEs. Each PTE may administer only one OFE except cases of mergers or takeovers when one PTE may temporarily administer more than one OFE. Regarding to voluntary pension plan, only investment 
funds, life insurance companies or specially established company pension funds are allowed to administer IKE. It is possible to have two or more PPE in one company. Employees may freely divide or transfer capital between them according to the contract concluded between employer and employees delegation which precedes the PPE establishment.

104. In the Slovak Republic, only certain institutions are authorized to administer pension plans during the contribution phase: PAMCs (mandatory pillar) and SPMC (voluntary pillar). The set-up of each PAMC and SPMC is pre-conditioned by granting a licence awarded by an independent market regulator the Financial Market Authority. Granting the licence required meeting tough conditions, incl. the minimum equity of the new company, transparency in ownership structure, /fit and properness of company's top representatives, professional background of the new administrator as well as track record of company's founders, etc. PAMCs and SPMC have also been required to prove the appropriate professional qualifications and experience of the pension asset manager, etc. The number of these types of companies has not been limited.

105. In Russia, mandatory funded pension system is administered by: Pension Fund of the Russian Federation (no licensing required) or Private pension funds licensed to act as insurers under mandatory pension insurance. Asset managers selected on a tender basis and complying with requirements established by law manage investments of both Pension Fund of the Russian Federation and private pension funds. Insurance companies as pension plan operators do not participate in these relationships.

106. All pension fund administrators in South Africa must be approved and licenced by the regulator before they are allowed to perform any administrative function. In the case of a new fund, the plan sponsor (employer) will choose the administrator, however after the fund has commenced and a board of trustees is in place it would be their responsibility to appoint an administrator to the fund.

107. In Turkey, only authorized entities called "pension companies" can administer these pension plans during all the phases. Also, the pension company is obliged to work with a portfolio management company for the management of the fund portfolio. Currently, there are 11 pension companies operating in Turkey. There is no maximum limit for the institutions that can be chosen by the members.

Table 4

\begin{tabular}{|l|l|}
\hline \multicolumn{1}{|c|}{ Country } & \multicolumn{1}{c|}{ Pension administrator institutions } \\
\hline Australia & Trustee company, sometimes insurance companies. \\
\hline Chile & $\begin{array}{l}\text { Pension fund management companies (mandatory pension plans). Banks, mutual funds, } \\
\text { insurance companies, housing fund managers (voluntary pension plans). }\end{array}$ \\
\hline Czech Republic & Pension companies. \\
\hline Estonia & Pension fund management companies. \\
\hline Hong Kong (China) & MPF scheme: trustee. ORSO schemes: bank, insurance company. \\
\hline Hungary & Pension fund companies (voluntary). \\
\hline Ireland & $\begin{array}{l}\text { In case of PRSA: Qualifying Fund Managers (QFM), in case of occupational pension plan: } \\
\text { the employers appoint them. }\end{array}$ \\
\hline Israel & \begin{tabular}{l} 
Any institution can administer pension plans except for banks and labour associations. \\
\hline
\end{tabular} \\
\hline
\end{tabular}




\begin{tabular}{|l|l|}
\hline Italy & $\begin{array}{l}\text { Banks, insurance companies, and investment firms or asset management companies (closed } \\
\text { pension fund). Financial intermediaries (closed pension fund). }\end{array}$ \\
\hline Latvia & The state asset manager (State Treasury) and private pension funds. \\
\hline Mexico & Pension fund management companies (AFOREs). \\
\hline Peru & Pension fund management companies (AFPs). \\
\hline Poland & $\begin{array}{l}\text { In frame of OFE, General Pension Societies (PTE), in frame of PPE and IKE investment } \\
\text { funds, life insurance companies or specially established company pension funds. }\end{array}$ \\
\hline Russia & Pension Fund of the Pension Federation, private pension funds. \\
\hline Slovak Republic & $\begin{array}{l}\text { In the framework of the mandatory pension plan: Pension asset management company } \\
\text { (PAMC), in the frame of the voluntary pension plan: Supplementary pension management } \\
\text { company (SPMC). }\end{array}$ \\
\hline South Africa & Pension fund administrator. \\
\hline Turkey & Pension companies. \\
\hline
\end{tabular}

\section{Frequency of switching between administering institutions by pension plan members}

108. There are portability standards in Australia that allow a trustee of a fund to refuse to transfer a balance to another fund if the member has already made one such request in a twelve month period.

109. In Chile, in a mandatory saving account there is a minimum stay requirement of six months, which was implemented in an effort to bring down administrative costs and prevent frequent rotation of workers among AFPs. For a voluntary saving account there is no limitation for switching between different institutions, although administrators may charge a commission. In practice, this commission has never been charged.

110. In the Czech Republic, a participant whose supplementary pension insurance was terminated and who is not entitled to a pension and has not been paid a termination settlement ${ }^{11}$ shall be entitled to a transfer of his contributions, including the state contribution and his share of the pension fund's revenues, to supplementary pension insurance with another pension fund, if such other pension fund so agrees. If a participant requests the transfer of financial means, the pension fund shall be obliged to execute the transfer no later than three months after the termination of supplementary pension insurance. The consent of the pension fund shall be attached to the request for the transfer of financial means.

111. In Estonia, a person can change II pillar pension fund once a year. In the third pillar there are no limits.

112. In Hong Kong (China) in the framework of MPF Schemes, the choice of administering institution rests with employers. Pension plan members have not got a choice and there is no statutory limit as to frequency of switching between administering institutions by employers. In the framework of ORSO

\footnotetext{
11 "Termination settlement payments" can be received when a member decides toterminate his plan, provided that they have paid at least 12 months of contributions; are not receiving benefits; and they do not transfer their assets to another pension company), or when the member dies and has not yet received pension benefits or a lump-sum payment.
} 
Schemes, the choice of administering institutions normally rests with employers. There is no statutory limit as to frequency of switching between administering institutions.

113. In Hungary, there is no legal limitation related to frequency of switching between administering institutions, only the by-laws can regulate this.

114. In Ireland, there are no legislative limits on such switching. There may be administrative limits i.e. where plan administrator allows first switch to be free but imposes charges eg 0.25 per cent for further switching. All switching in relation to investments of PRSA assets are free.

115. In Israel there is no limitation in terms of switching between different pension institutions.

116. In Italy, the choice of the asset manager in closed pension funds rest with the employer. An agreement must be signed between the governing board of the closed pension fund and the asset manger. There is no rule regarding to frequency of switching between external investment managers. Participants of open pension funds have the possibility of transferring contribution accrued in their account to another fund without changing employer.

117. In Latvia, according to the State-funded Pension Law, a participant of the state-funded pension plan may switch between different asset management companies once a year. In addition, a member may switch to any other asset management company if a license of the asset management company is revoked or if a reorganization of asset management company takes place.

118. In Mexico, members are free to change from one AFORE to another. However, if they decide to contribute to a new AFORE, they must also transfer all their existing balance to the new AFORE, because an affiliate can only have saving with only one Fund Administrator. Since the introduction of the system, there has been a concern about the frequency of switching, thus measures have been introduced to ensure that a transfer may be made only once a year.

119. In Peru, members can switch from one AFP to another after a minimum of six consecutive months of contributions. In order to switch the affiliates has to go the AFPs' office and sign the transfer forms. Further, a fixed fee is charged per transfer payable to the AFP that the affiliates wish to leave.

120. In Poland in the case of IKE, there are no limits in the frequency of switching between administering institutions. In the case of OFE, there are no limits, but if done sooner than 2 years after the previous switch, a special fee is to be paid. In the case of PPE, it is according to the contract concluded between employer and employees delegations, which precede the PPE establishment.

121. In Russia, the choice of an asset manager or private pension fund may be made once a year by filing the respective application not later than December 31 of the current year. Before September 1 each participant will receive a statement from the fund on the balance of his individual account. Thus far switching is free of charge. The right to choose an asset manager or pension fund is available to participants who have not reached the age five years less than the normal pensionable age.

122. In the Slovak Republic, a member of the mandatory pension plan can conclude a new agreement on pension saving managed by other PAMC within 6 months since the day of concluding an agreement on pension saving with the respective PAMC. Members shall not conclude an agreement on pension saving with another PAMC within 1 year since the day of concluding a first agreement on old-age pension saving with the respective PAMC. No other limitations are stipulated in law. In the supplementary pension plans there is no limitation for switching between administering institutions. SPMC is obliged to inform its clients about the fees and other limitation in the case of switching before concluding the contract (in their annuity plans). 
123. In South Africa, the change in administrators will be done by the board of trustees of a fund and not by the pension plan members, except if an individual belongs to a Retirement Annuity fund, without any link to employment, then the individual be in a position to request the transfer of membership to another RA fund. On the frequency of switching administrators there is no limitation.

124. In Turkey, the members can switch to another pension company once a year. No fees are involved for switching, but the pension company may deduct the entry fee in cases where it was deferred during the entrance.

Table 5

\begin{tabular}{|c|c|}
\hline Country & $\begin{array}{c}\text { Frequency of switching between administering } \\
\text { institutions }\end{array}$ \\
\hline Australia & Every twelve months. \\
\hline Chile & Every six months. No fee of switching. \\
\hline Czech Republic & No limit. No fee of switching. \\
\hline Estonia & Just in case of II.pillar: every twelve months. No fee. \\
\hline Hong Kong (China) & MPF and ORSO schemes: No statutory limit. \\
\hline Hungary & No limit, there is a fee. \\
\hline Ireland & $\begin{array}{l}\text { No limit. In case of PRSA: free, in case of occupational } \\
\text { pension plan: first time is free, then } 1.4 \% \text { of assets. }\end{array}$ \\
\hline Israel & No limit. No fee. \\
\hline Italy & No legal rules. \\
\hline Latvia & Every twelve months. \\
\hline Mexico & No limit. No fee. \\
\hline Peru & Every six months. No fee. \\
\hline Poland & $\begin{array}{l}\text { IKE: No limit. } \\
\text { OFE: No limit. A special fee is to be paid. } \\
\text { PPE: According to the contract concluded between }\end{array}$ \\
\hline Russia & Every twelve months. There may be fee. \\
\hline Slovak Republic & Mandatory: Every six months. No fee. \\
\hline South Africa & No limit. No fee. \\
\hline Turkey & Every twelve months. No fee. \\
\hline
\end{tabular}




\section{Default institution}

125. The following table shows that in most countries (Chile, Czech Republic, Estonia, Hong Kong (China) Hungary, Israel, Italy, Peru, and Turkey) there is no default institution specified. But, in Australia the legislation that introduced choice of fund provides that an employer must nominate a default fund if an eligible employee does not make an active choice.

Table 6

\begin{tabular}{|c|c|}
\hline Country & Specified default institution \\
\hline Australia & $\begin{array}{l}\text { Yes, the employer must nominate a default institution if } \\
\text { the eligible employee does not make an active choice. }\end{array}$ \\
\hline Chile & No default institution. \\
\hline Czech Republic & No default institution. \\
\hline Estonia & No default institution. \\
\hline Hong Kong (China) & No default institution. \\
\hline Hungary & No default institution. \\
\hline Ireland & $\mathrm{n} / \mathrm{a}$ \\
\hline Israel & No default institution. \\
\hline Italy & No default institution. \\
\hline Latvia & Yes, the State Treasury is the default institution. \\
\hline Mexico & Yes, when member does not make an active choice. \\
\hline Peru & No default institution. \\
\hline Poland & Just in OFE plans. \\
\hline Russia & Asset manager appointed by the Government. \\
\hline Slovak Republic & No default institution. \\
\hline South Africa & $\mathrm{n} / \mathrm{a}$ \\
\hline Turkey & No default institution. \\
\hline
\end{tabular}

126. In Ireland, the question is not applicable for occupational pension plans.

127. In Latvia, for the mandatory pension scheme, an investment plan managed by the State Treasury is a default institution for the participant that does not make an active choice of asset manager. This 
procedure will be changed in the near future but no legislative changes have been adopted yet. The exact criteria for a participant who has not intended to make an active choice of asset management companies will be provided in the near future.

128. In Mexico, members who do not choose an investment institution when joining the pension system are assigned by the supervisory authority to one of the three cheapest AFOREs (Administrators).

129. In Poland, the default institution is relevant only in case the of the OFE plan. Members are attributed on a random basis to funds that meet the following criteria in the last two moments the assetweighed market averages are calculated: less than 10 per cent share in the assets-weighed market and morethan-average 36-month rate of return. In case no fund meets these criteria, only the last calculation moment is taken into consideration.

130. In Russia, by default, pension assets are managed by the public asset manager to be appointed by the Government of the Russian Federation (currently, Vneshekonombank, a public bank). By law the public asset manager may make investments almost exclusively into government securities.

131. In the case of Slovakia, the member who is obliged to participate in the Mandatory pension plan and does not conclude an agreement on a mandatory pension plan within 30 days of the day on which he/she became obligated to participate in the mandatory pension plan, the Social Insurance Agency shall designate a PAMC in which the saver shall participate in Mandatory pension plan as follows: the Social Insurance Agency shall designate the PAMC having the lowest amount of remuneration for managing the pension fund; if the amount of remuneration is equal to the remuneration of several pension administration companies, the Social Insurance Agency shall set up a list of these PAMCs in alphabetic order, gradually designating a pension administration company according to this list. The saver who is designated a PAMC by the Social Insurance Agency is automatically a saver of the conservative fund of that pension administration company.

132. In South Africa, the member does not choose the administrator (this is the responsibility of the board of trustees), this question is not applicable.

\section{Key issues regarding choice of products and portfolio}

\section{Products as financing vehicles and portfolio choice by members}

133. In Australia, in the personal pension plans, during the contribution phase, mandated contributions must be made to a complying superannuation fund operated as a trust by a trustee and non-mandated contributions may be made to a non-complying superannuation fund however they will not attract tax concessions. Rollover amounts may be paid into a superannuation fund or specialist rollover funds known as Approved Deposit Funds (ADFs) or to a deferred annuity product offered by a life insurance company. Funds may be unitized or unit linked or a crediting rate may be applied. Superannuation funds may invest into mutual funds as well as directly invest. In the case of occupational DC funds, the plan sponsor would generally choose the structure of the fund. Members may exert portfolio choice in most DC funds during the contribution phase. As Retirement Savings Accounts are capital guaranteed there is no portfolio choice available.

134. In Chile, mandatory contributions may be paid exclusively in pension funds, whilst voluntary contributions may be paid in banks, mutual funds, insurance companies and others. Investment portfolio choice was introduced in the mandatory pension system in 2000. At this time, AFPs were allowed to offer only two types of pension funds. The new multifunds system implemented in 2002, requires to each AFP offer four different types funds, but it may also offer a fifth fund. Thus, the members can chose between five different investment choices. Additionally, members can allocate their contributions between two 
different funds within one AFP, in whatever proportion they want, which allows for achieving a closer approximation to the risk return preference of each member. The new design allows the affiliates to choose freely among the different funds. The only limitation is for pensioners, male members over 55 years old and female members over 50 years old. Pensioners may choose only the Funds C, D and E, which have a lower relative risk, whilst members who are within 10 years or less of the legal retirement age may access to the fund type B, C, D and E.

135. In the mandatory pension plan in Estonia, the contributions can be paid only into pension funds. Portfolio choice was introduced from the inception of the mandatory second pillar of the pension system (May 2002). Individuals can choose among three kinds (aggressive, medium and conservative) of portfolio. In III pillar there is choice of product (pension insurance with guaranteed interest -different options like lifetime pension insurance with life insurance, term pension insurance with life insurance- and pension insurance with investment risk -unit-linked, investment insurance, fund contract, growth portfolio).

136. In Hong Kong (China), in the case of MPF Schemes, employers must choose from MPF schemes registered by the regulator. MPF schemes must be set up as trusts. Members who are employees choose from the fund options of the MPF scheme chosen by their employers. Self employed persons can choose the scheme and the fund option. In case of ORSO Schemes there is no statutory maximum number of fund options; no statutory restrictions on whether the plan sponsor or the employees are responsible for choosing fund options. It depends on the governing rules of the plan.

137. In Hong Kong (China), in the framework of both MPF and the ORSO Schemes, if once a member chooses a fund option, the portfolio choice rests with the fund manager of the fund. Members cannot exert choice of the asset under a fund option.

138. In Hungary, the portfolio choice is available for the members in case of only five voluntary pension funds. Investment portfolio rules depend on the funds. The regulations do not set any limits on the number of options that can be offered.

139. In Ireland, the personal pension plans offer a special product called PRSA. The investment of that can be only in pooled funds. Members can exert portfolio choice in both the personal and the occupational pension plans. In the case of occupational pension plans there are several options as to how the investment power may, or should, operate. The responsibilities of the trustees will vary depending upon the route chosen. Typically trust deeds may allow the following range: conferring upon the trustees an absolute discretion as to the manner in which fund contributions are invested; conferring an option for the member to determine the manner in which his/her contributions are invested, perhaps from a range of funds chosen by the trustees; and conferring an unrestricted option for the member to invest certain proportions of his/her contributions in particular sectors at particular ages and in default of the exercise of such an option, for absolute discretion to be reserved to the trustees. The legislation provides that where and to the extent that the rules of the plan provide for the trustees to invest the resources of the plan as directed by the members, and the trustees comply with requirements as laid down in legislation they will be exempt from any liability for the consequences of the members' investment decision. Good practice recommends that trustees should aim for a range of investment options which will not overwhelm members and that sufficient information be given to allow an appropriate choice to be made. The trust deed and rules will set out the trustees' investment powers which are usually unrestricted in relation to the investment vehicles, subject to acting prudently in the best interests of the members.

140. In Israel, only pension fund and life insurance policies - such as unit-linked products can be used as financing vehicles. Members can exert portfolio choice within each product, during the contribution phase only. There is no regulatory limit on the number of portfolios from which members may choose. The 
number of portfolios in each product usually does not exceed seven. The types of portfolio are not regulated, nor are there regulatory quantitative limits by asset class.

141. In Italy, contributions in the supplementary pension schemes may be contributions may be paid bank, insurance company, and investment firm or asset management companies. Recently, portfolio choice by participants has become more widespread. All open pension funds offer individuals the choice between 3-5 portfolio options, with different risk profiles (typically from 0 per cent to 70-80 per cent of shares internationally diversified; often there is an option w. a guaranteed rate of return). At their start-up, most closed-end funds did not offer investment choice to individual members. They then introduced or are now introducing choice (3-4 portfolio options, similar to those of open pension funds).

142. In Latvia, individual choice of portfolio was set up at the same time that members were allowed to choose the asset manager, coming into operation in January 2003. The aim of this scheme is to increase the amount of pensions using investment mechanisms that are adapted to the individual needs of each member of the SFPS. The key tool is to offer members three options with different combinations of investment instruments. The funds are differentiated according to quantity of fixed income and equity instruments in which savings are invested.

143. In Mexico, contribution can be paid only in pension funds. Investment choice was implemented in January 2005. Under this new scheme the members of the private pension system can choose only one of the two funds offered by each AFORE.

144. In the mandatory pension plan in Peru, only a registered pension fund may be used to provide for retirement provision. Investment choice (multifunds system) will be in effect by November 2005. The new investment scheme allows the members to choose only one of the three funds offered by each AFPs.

145. In Poland, in the framework of OFE, during the accumulation phase there is no choice of products allowed. Investment portfolio choice is not allowed either. In case of PPE and IKE, the choice of product and portfolio depends on their statutes.

146. In Russia, essentially, the choice of portfolio is related to the asset manager if the insured person stays with the PFR. The asset manager should declare investment goals, guidelines and risks for the portfolio in the form of investment declaration. One asset manager may offer more than one portfolio but few have chosen to do so. If the insured person chooses a private pension fund, he trusts the fund to choose an asset manager and investment strategy.

147. In the Slovakian mandatory pension plan only pension funds are used as products, whilst in voluntary pension plans, from 1 January 2005, not only supplementary pension insurance companies but also other financial institutions - banks, life assurance companies, PAMCs and security traders (special purpose saving) can adminsiter SPMCs as part of the voluntary pension schemes. Under the system of mandatory pension plans, members may choose among three types of investment portfolio offered by each PAMC, which differ in the investment strategy. Individuals can only be a member of one portfolio. In case of the supplementary pension funds, each SPMC operates two types of funds, which differ in their structure of investment portfolio.

148. In South-Africa, only a registered pension fund may be used to provide for retirement provision. Individuals' investment choice will be determined in terms of the rules of the fund.

149. In Turkey, there is no choice of product and members can only switch between pension mutual funds. In Turkey, the pension contributions should be invested through special financing vehicles called "pension mutual funds". These mutual funds are funds that have to be established by the pension companies solely for the purpose of pension investment. As of September 2005, the number of pension mutual funds is 
91. The choice of the member is limited to the selection of pension mutual funds offered in the pension plan. Each pension company should establish at least 3 different pension mutual funds with differing risk characteristics. (i.e. pension mutual funds with low-medium-high investment risks) There are pension plans in which only 1-2 pension mutual funds are offered whereas some plans have a much wider selection of pension mutual funds.

\section{Quantitative limits ${ }^{12}$ by asset class for each portfolio}

150. In Australia, there are no quantitative limits on asset class, merely a general directive that the trustee takes into account the diversification and liquidity requirements of the fund

151. The Chilean multifunds system requires each AFP to offer four different types of funds, called simply Funds B, C, D and E, which vary according to the degree of risk. AFPs may also offer voluntarily a Fund A. The funds are differentiated mainly by the proportion of their portfolio invested in variable income securities. Additionally, the limit on foreign investment is between 20 per cent and 30 per cent, which is applied to total investment for all the funds in each AFP. The quantitative limits for investment in equities are as follows:

Table 7 -Maximum and minimum limits in equities by type of funds in Chile (As a \% of the value of each fund)

\begin{tabular}{|c|c|c|}
\hline Type of fund & Maximum limit in equities & Minimum limit in equities \\
\hline A & $80 \%$ & $40 \%$ \\
\hline B & $60 \%$ & $25 \%$ \\
\hline C & $40 \%$ & $15 \%$ \\
\hline D & $20 \%$ & $5 \%$ \\
\hline E & 0 & 0 \\
\hline
\end{tabular}

152. In the voluntary private pension scheme in the Czech Republic, portfolio diversification rules do not make any difference among the different classes of pension funds, which means that each pension fund company is free to decide its own rules within the general framework of the law. The general diversification requirements include: the investment in securities from the same issuer is limited to 10 per cent of the fund's assets (not valid for State bonds); the bank deposit in one bank is limited to 10 per cent; the value of one piece of real estate must not exceed the 5 per cent. Additionally, the pension funds assets cannot include more than 20 per cent of the total nominal value of shares issued by the same company. Finally, foreign investment is permitted only in the case of securities (bonds) issued by the Organization for Economic Co-operation and Development (OECD) member states or by central banks of OECD member States.

153. In Estonia, under the second pillar the pension management companies offer to their members three different investment portfolios, which vary mainly in the proportion of equities in every fund. The quantitative limits for the three funds are as follows:

12 More information in the document "Survey of Investment Regulation of Pension Funds" DAFFE/AS/PEN/WD(2004)1 for details. 
Table 8 -Maximum investment limits in Estonia (As a \% of the value of each Fund)

\begin{tabular}{|c|c|c|c|}
\hline & Conservative & Balanced & Aggressive \\
\hline Variable Income (Equities) & $0 \%$ & $25 \%$ & $50 \%$ \\
\hline Fixed-Income Securities (Bonds) & $100 \%$ & $75 \%$ & $50 \%$ \\
\hline
\end{tabular}

154. In Hong Kong (China), in the case of both the MPF Schemes and the ORSO Schemes, there are no statutory quantitative limits by asset classes.

155. In Hungary, there is no special regulation on investment for the 5 pension funds that provide the choice of portfolio.

156. In Italy, in the case of both the closed pension schemes and the open pension schemes, there are no statutory quantitative limits by asset classes.

157. In Latvia, according to the risk level of pension funds, the investment choices available for individuals may be divided into conservative, balanced and active plans. The Conservative fund can invest only in promissory notes, bonds, banks' deposits and in other financial instruments having a fixed yield. The Balanced fund's assets may be invested in shares to the extent of 15 per cent of the market value of the Fund's assets. The Active fund can invest up to 30per cent of the investment portfolio in shares.

158. In April of 2004, the National Commission of the Saving System for Retirement in Mexico authorized a new investment scheme of the saving system for retirement. Each AFORE can offer two SIEFORES with different investment alternatives for their mandatory contribution in accordance with individuals' investment profile and preference. SIEFORE Basica 1 can invest only in fixed income securities, local and foreign. Additionally, there is a minimum investment quota of 51 per cent in inflationprotected securities issued by the government or in corporate or municipal bonds with rating comparable to those of Mexican Treasury bonds. SIEFORE Basica 2 can invest in local and foreign debt securities and in equities through Principal Protected Notes (PPN) linked to approved index. The investment limit for equity investment is 15 per cent of the assets of the SIEFORE. The exposure in foreign assets has a limit of 20 per cent of the total SIEFORES portfolio.

159. According to the new Peruvian Multifunds Law (2004), each AFP can offer more than one fund with no limit for the total number of funds. However, there are limits of investment in the regulation for only three types of funds; therefore, the AFPs have decided to start all three of the funds but, in reality, listening additional funds is optional. Thus, each AFP will offer three types of pension funds: a Conservative Fund, a Mixed Fund and an Aggressive Fund. The quantitative limits for each portfolio are established according to four categories of securities: variable income securities, fixed income securities, derivative instruments and short term instruments. In addition, the operative limit on foreign investment is 10.5 per cent, which is applied to total investments for all the funds in each AFP Consequently, the investment limits for each of the funds have the following characteristics: 
Table 9 -Maximum investment limits in Peru (As a \% of the value of each Fund)

\begin{tabular}{|c|c|c|c|}
\hline & Conservative & Mixed & Aggressive \\
\hline Variable Income (Equities) & $10 \%$ & $45 \%$ & $80 \%$ \\
\hline Fixed-Income Securities (> 1 year) & $100 \%$ & $75 \%$ & $70 \%$ \\
\hline Derivative Instruments & $10 \%$ & $10 \%$ & $20 \%$ \\
\hline Short Term Instruments & $40 \%$ & $30 \%$ & $30 \%$ \\
\hline
\end{tabular}

160. In Poland, there is no individual choice of investment portfolio in case of OFE. In case of PPE and IKE, the quantitative limits depend on their statues.

161. In Russia, requirements to the structure of investment portfolio, investment policy and asset manager are established within the general framework of the law. There are a number of limits aimed at diversification of investments. Some are set by law (such as the maximum share of the investment portfolio that can be held at banks ( 20 per cent) or invested abroad (20 per cent from 2010)), while others are set by the Government and are potentially more flexible. It should be mentioned that no minimum limits are set for any class of assets and no maximum limits are set for federal government securities. A number of limits aim to control the risks connected with investments in the securities of one issuer, in particular, securities of one issuer or a group of connected issuers in the investment portfolio should not exceed 5 per cent. All these limits should be observed by each management company; for the aggregate investment portfolio of the PFR, a limit is set at 30 per cent of the total volume of securities in circulation of any one issuer. Securities issued by the affiliated companies of the management company and the specialised depositary should not exceed 5 per cent of assets. For default option the maximum shares of the eligible asset classes are as follows: i) rouble-denominated government securities of the Russian Federation - 80\%; ii) foreign exchange denominated government securities of the Russian Federation - 80\%; iii) mortgage-backed securities $-40 \%$; iv) rouble and foreign currency accounts (USD and/or Euro) with credit organisations $20 \%$.

162. The existing regulation in Slovakia mandates each PAMC to offer three different investment portfolios to its members, which differ in investment strategy, name and the risk inherent in the appreciation of assets: (i) the Conservative fund seeks a low relationship risk-return, hence the assets in this fund may be invested only in bond and money market instruments and for transactions to constraint the currency risk. The assets in this fund are 100 per cent inflation protected securities. Assets in this fund may attain the maximum mean modified duration in the value 2. Modified duration expresses the relation of change in the assets value in pension fund upon a unit change of interest rate that directly or indirectly affects the value of assets in pension fund. (ii) The Balanced fund has a moderate risk-return relationship. The investment regime approved the equity exposure of this fund up to 50 per cent of the value of assets, and additionally, there is a minimum investment quota of 50 per cent of bonds and money market instruments. (iii) The Growth fund can invest up to 80 per cent of the value of assets in equities, and there is no minimum invested quota in bonds or money market instruments. Additionally, the Law states that the investment into the instruments issued by Slovak issuers shall be at least 30 per cent of the funds' portfolio. 
Table 10 -Investment limits of the second pillar pension funds in Slovakia (As a \% of the value of each fund)

\begin{tabular}{|c|c|c|c|}
\hline & Equities & $\begin{array}{c}\text { Bond and Money Market } \\
\text { Instruments }\end{array}$ & Risk \& Return \\
\hline Growth Funds & Up to $80 \%$ & no limit & middle \\
\hline Balanced Fund & Up to $50 \%$ & at least $50 \%$ & low \\
\hline Conservative Fund & no equity exposure & $100 \%$ & low \\
\hline
\end{tabular}

163. As regards voluntary pension plans in Slovakia (third pillar), each SMPC is obliged to manage no less than 2 funds with different investment profiles: at least one so-called "subscription" pension funds and only one "paying-out" pension fund. (i) The "subscription" pension funds shall follow the same general principles, which are stipulated in the Law on second pillar and in the statute of the fund. The law lays down no other restrictions or limitations related to the investment profile. (ii) When a member asks for redemption of benefits, the pension management company is obliged to transfer its balances from the "subscription" pension fund to the "Paying-out" pension fund. The investment profile of this fund has to follow the same investment profile and limits as the conservative pension fund in the second pillar.

164. In South Africa, the Pension Funds Act stipulates general maximum limits for the investment in certain asset classes. Specific quantitative limits by asset classes for each portfolio are determined in terms of the rules of the fund.

165. In Turkey there are quantitative limits set by asset class. A minimum of 24 per cent of the contributions should be invested in government domestic borrowing instruments. Investment in foreign investment instruments are capped at a maximum of 15 per cent of the contributions.

\section{Frequency of switching between products and portfolio}

166. The switching between products is not applicable in countries such as the Czech Republic, Hong Kong (China), Hungary, Italy, Mexico, Poland, Slovakia, South Africa and Turkey.

167. In Australia, fund trustees may use fees and charges to discourage switching or impose their own limits on the frequency of switching, however there are no legislative limits on the frequency of switching between portfolios by fund members

168. In Chile, members may transfer any of their balances no more than twice in one calendar year between the funds of the same Administrator, whether mandatory contributions, voluntary contribution of their voluntary saving account.

169. There is no limit for the frequency of switching between portfolios by pension plan members in Ireland and not applicable in case of Czech Republic.

170. In Estonia, the regulation lets individuals change their portfolio only once a year in the mandatory pillar. In the third pillar there are no limits.

171. In Hungary, the rules depend on the funds. Only one of the five voluntary pension funds allows the daily changing of portfolio, the others let the voluntary pension funds members have possibility to change their portfolio once in a quarter, or a year. 
172. There is no limit for the frequency of switching between different portfolios by pension plan members in Israel.

173. In Italy, there are no rules relating to switch between different individual investments choices.

174. In Latvia, affiliates to the second pillar may choose only one investment plan at a time. Members are allowed to switch between different investment plans twice a year, only if both investment plans are managed by the same asset management company. In the case that a member wants to choose a portfolio managed by another management company, members are allowed to change their investment plan once a year.

175. In Mexico, the affiliates may transfer their balance from on fund to another fund (within the same Administrator) without any restriction or cost.

176. In Peru, members may freely transfer their balance, consisting of mandatory contributions and voluntary saving between the three Funds, every three months.

177. In Poland, in the case of PPE and IKE, the limit for the frequency of switching depends on their statutes.

178. In Russia, the switching between portfolios annually allowed not later than December 31 .

179. In the mandatory pension plan in the Slovak Republic, a member willing to adjust his/her investment profile can switch between funds any time without limitation (the change is for free). In case of the system of supplementary pension plan frequency of switching between portfolios is not limited.

180. In South Africa, the rules of the funds will determine any specifics relating to individual investment choice.

181. In Turkey, the member can switch between pension mutual funds (but not between individual asset compositions in the pension mutual fund). The number of switches between different pension mutual fund compositions is limited to 4 times a year.

Table 11

\begin{tabular}{|l|l|}
\hline \multicolumn{1}{|c|}{ Country } & Limits in the frequency of switching between portfolios \\
\hline Australia & No, but fund trustees may impose their own limits. \\
\hline Chile & Twice in one calendar year. \\
\hline Czech Republic & Switching between portfolios is not allowed. \\
\hline Estonia & Yes, only in case of the second pillar: once a year. \\
\hline Hong Kong (China) & Switching between portfolios is not allowed. \\
\hline Hungary & The funds can determine the rules. \\
\hline Ireland & No limits. \\
\hline
\end{tabular}




\begin{tabular}{|l|l|}
\hline Israel & No limits. \\
\hline Italy & The funds can determine the rules. \\
\hline Latvia & Yes, twice a year. \\
\hline Mexico & No limits. \\
\hline Peru & Yes, every three months. \\
\hline Poland & $\begin{array}{l}\text { OFE: Switching between portfolios is not allowed } \\
\text { PPE and IKE: it is up to their statutes. }\end{array}$ \\
\hline Russia & Yes, once a year. \\
\hline Slovak Republic & No limits. \\
\hline South Africa & The funds can determine the rules. \\
\hline Turkey & $\begin{array}{l}\text { Limited to } 4 \text { times a year (switching between different pension } \\
\text { mutual fund compositions). }\end{array}$ \\
\hline
\end{tabular}

\section{Legislation for default product and portfolio}

182. At present, in Australia the legislation does not specify a default product for members that do not make an active choice. However, the choice of fund legislation that commenced on 1 July 2005 requires the employer to choose a default fund. The legislation does not specify a default portfolio either for members that do not make an active choice. However, it does specify that the trustee must designate and identify a default option. In Australia, the default option is usually the balanced option.

183. In Chile, the pension law that establishes the default fund for those members who do not choose an investment fund varies by age. The rule divides the affiliates into three age bands, where men and women below 35 years old are assigned to fund Type B, which has a considerable stock component; men between 36 and 55 and women between 36 and 50, to fund C; and those who are older than 56 in the case of men and 51 in the case of women, to fund type D, with a higher intensity of fixed income. No affiliate is assigned to either Fund A or Fund $\mathrm{E}$ in case they do not make an active choice.

184. In the Czech Republic, the legislation does not specify a default portfolio for members that do not make an active choice.

185. In Estonia, the legislation does not a specify default portfolio in third pillar. In the second pillar, the default portfolio is the conservative pension fund.

186. In the case of MPF Schemes in Hong Kong (China), there is no statutory default portfolio; but the governing rules of the plan would typically specify a default fund option where a member's contributions would be invested if the member does not make an active choice of fund. Commonly, the default fund options would be a balanced fund or a capital preservation fund. There is no statutory default product within ORSO Schemes either. The default portfolio is not applicable because the portfolio (i.e. the asset allocation within a fund option) is decided by the fund manager. 
187. In Ireland, the legislation specifies a default investment strategy for PRSAs. The legislation does not specify a default portfolio for any other type of plan. In relation to defined contribution plans, the trustees may wish to consult the members and seek their input into the investment strategy to be pursued in relation to their individual account. In relation to PRSAs, the legislation does specify a default investment strategy (DIS). The DIS may only provide for investment in "pooled funds". Pooled funds are defined in the legislation to mean: "a collective investment scheme; or an internal linked fund the benefit of which is made available by means of a contract of insurance undertaking authorized to transact investment business in the State, whether by establishment, branch, or provision of services, that falls within Class III as set out in the annex to the Council Directive 79/267/ EEC of 5 March 1979". Any such pooled fund is required to have appropriate diversification of investments, including appropriate diversification of credit and counterparty risks, appropriate liquidity of investments, charges that are readily identifiable, unit or share prices that are determined on most working days, unit or share prices that are widely published not less frequently than weekly, and unit or share prices that are determined with regard for equity between different generations of unit holders or shareholders. A Standard PRSA may only have PRS assets that comprise investment in one or more pooled funds that comply with the criteria set out above.

188. In Israel, there is no default portfolio for members that do not make an active choice.

189. In Italy, the default investment portfolio typically continues the investment profile of the previous "single" portfolio.

190. In Latvia, for individuals who do not make an active decision of an investment plan within the first two months, there is a publicly managed default fund - the State Treasury. The fund was set up with 0 per cent of its portfolio in equity, making it substantively less exposed to risk than both the balanced (up to 15 per cent of equities) and the active fund (up to 30 per cent of equities).

191. In Mexico, under the new investment regime, the regulator Authority established the SIEFORE Basica 2 as the default portfolio option for all workers; except for those who are 56 or older, which are assigned to SIEFORE Basica 1, which is a fund free of variable income. Thus, the equity exposure was established by default with the purpose of increasing the expected yield of the funds.

192. In Peru there is no default product. The regulations consider that members who do not select a Fund type when joining the Pension System will be assigned to one according to their age. The rule established for assigning members to one of the three different Funds involves dividing them into two groups age-bands, with members younger than 60 years old being assigned to Mixed Fund (with more relative participation of equities), and members older than 60 years old will be automatically be part of the Fund with higher intensity of fixed income, Conservative Fund.

193. In Poland, for mandatory pension plans (OFE) there is no default portfolio. In case of PPE and IKE, the default product and default portfolio depends on their statutes.

194. In Russia, there exists a default option in favour of insured individuals who failed to exert their choice of investment portfolio. In this case, pension savings passed to Vneshekonombank ${ }^{13}$.

195. In Slovakia the default portfolio is the conservative fund.

196. In South Africa, the board of trustees is responsible for providing guidance on the choices between which the members may choose and a default option where no option has been made.

\footnotetext{
${ }^{13}$ The investment policy and quantitative limits of the Vneshekonombank are detailed in the section related to quantitative limits.
} 
197. In Turkey, regarding a default portfolio, the legislation doesn't specify a default option for the members that do not make an active choice. However, according to the regulation, it is mandatory for the pension company to conduct a risk analysis of the member before the choice of the pension mutual fund. Then, the pension company is supposed to make a recommendation according to the risk profile of the member.

Table 12

\begin{tabular}{|c|c|}
\hline Country & Specified default portfolio \\
\hline Australia & The default portfolio is usually the balanced option. \\
\hline Chile & $\begin{array}{l}\text { The default portfolio varies according to the age of the } \\
\text { member. }\end{array}$ \\
\hline Czech Republic & n/a. \\
\hline Estonia & The default portfolio is the most conservative option. \\
\hline Hong Kong (China) & No default portfolio. \\
\hline Hungary & $\begin{array}{l}\text { The default portfolio is usually the most popular or } \\
\text { conservative option. }\end{array}$ \\
\hline Ireland & $\begin{array}{l}\text { No default portfolio, but in case of PRSA there is default } \\
\text { strategy. }\end{array}$ \\
\hline Israel & No default portfolio. \\
\hline Italy & The investment profile of the previous "single" portfolio. \\
\hline Latvia & $\begin{array}{l}\text { The default portfolio is the publicly managed default fund - } \\
\text { the State Treasury (conservative option). }\end{array}$ \\
\hline Mexico & $\begin{array}{l}\text { The default portfolio varies according to the age of the } \\
\text { member. }\end{array}$ \\
\hline Peru & $\begin{array}{l}\text { The default portfolio varies according to the age of the } \\
\text { member. }\end{array}$ \\
\hline Poland & $\begin{array}{l}\text { OFE: Switching between portfolios is not allowed. } \\
\text { PPE and IKE: it is up to their statutes. }\end{array}$ \\
\hline Russia & The default portfolio is the most conservative option.. \\
\hline Slovak Republic & The default portfolio is the most conservative option. \\
\hline South Africa & No default portfolio. \\
\hline Turkey & No default portfolio. \\
\hline
\end{tabular}




\section{Fees for switching between portfolios}

198. Fees concerning changing portfolio are called switching fees. These are special fees in the sense that they arise from a decision taken by members. In some cases they are linked to asset size, whilst in other cases they are made up of a fixed fee.

199. In Chile, the Administrator of mandatory and voluntary contribution may charge a commission in the case of more than two changes of portfolio in one year. The aim of this commission is to avoid excessive administration costs and the possibility of negative effects on the Chilean capital market. The commission cannot be deducted from the pension fund, thus the member has to pay it directly.

200. In Estonia, if the individuals want to transfer the assets to a new alternative, it is necessary also to pay unit issue and redemption fees.

201. In Hungary, the switching fees depend on the pension funds.

202. In Ireland, some PRSA providers limit the number of times a year that contributors can switch or change funds without charge.

203. In Peru, in the case of more than four transfers of the investment portfolio in one calendar year, the administrator is authorized to charge an exit commission, which cannot be deducted from the Pension Fund.

204. In Russia, switching between portfolios is currently free of charge.

205. In Slovakia, PAMCs do not charge remuneration or fee for switching from a pension fund to another one managed by the same PAMC.

Table 13

\begin{tabular}{|l|l|}
\hline \multicolumn{1}{|c|}{ Country } & Fees in the frequency of switching between portfolios \\
\hline Australia & Yes, in the case of more than one transfer. \\
\hline Chile & Yes, in the case of more than 2 transfers in a year. \\
\hline Czech Republic & Switching between portfolios is not allowed. \\
\hline Estonia & Yes. \\
\hline Hong Kong (China) & Switching between portfolios is not allowed. \\
\hline Hungary & Yes, but the first time is free in case of some pension funds. \\
\hline Ireland & Yes, in case of some PRSA providers. \\
\hline Israel & n/a. \\
\hline Italy & n/i. \\
\hline Latvia & Switching between portfolios is allowed only twice a year. \\
\hline
\end{tabular}




\begin{tabular}{|l|l|}
\hline Mexico & No fee. \\
\hline Peru & Yes, in the case of more than 4 transfers in a year. \\
\hline Poland & $\begin{array}{l}\text { OFE: Switching between portfolios is not allowed. } \\
\text { PPE and IKE: it is up to their statutes. }\end{array}$ \\
\hline Russia & No. \\
\hline Slovak Republic & No fee. \\
\hline South Africa & The fees depend of the rules of fund. \\
\hline Turkey & No fee. \\
\hline
\end{tabular}

\section{Modalities for changing administering institution, product, portfolio}

206. In Australia, members may request the trustee of the current fund to transfer or rollover the member's interest to another fund. The transaction is called an eligible termination payment (ETP) and documents describing the transaction, the composition of the amount and tax rates for each component are called ETP roll-over statements. Copies of the documents must be given to the member and the receiving fund within 30 and 7 days respectively. Funds offering investment choice generally provide call centre or Internet service to arrange for switching of investment choices. Retail funds that use financial advisers to assist members with their investment choices often provide for the adviser to arrange the switch.

207. In Chile, those workers who want to transfer the balance in their individual accounts between Administrators must sign a transfer order with the new AFP. Additionally, the transfer requirements oblige workers to hand in a photocopy of their ID Card and the latest statement of their AFP. The invested funds can be transferred from one fund to another only by signing a transfer form with the AFP.

208. In the Czech Republic, participants may change their portfolio through requests to the new pension funds, after filling their transfer forms. The rest of administration will provide the new pension funds.

209. In Estonia, to change fund, a person must submit a corresponding form. It's possible to do this in bank offices, insurance companies, Internet banks (by password) and through the Central Register of Securities website.

210. In Hungary, switching depends on the pension fund company's rule. Some allow members to change their portfolio by calling the call-center in addition to the traditional letter, and others accept emails as well.

211. In Hong Kong (China), in the framework of both MPF and ORSO schemes, the choice of administering institution (i.e. the trustee) rests with the employer. The employee member cannot initiate a change of institution. For changing fund options, members can do this through Internet with password, fax, mail, etc. In the case of ORSO schemes, the documents may also be submitted to the trustee via the employer.

212. In Mexico, to change administrator, the members need to sign a transfer order with the new AFORE. In order to transfer the balance from one SIEFORE to another, the member (younger than 56 years) has to fill a "Demand of Transfer" in order to make the transfer. 
213. In Peru, there are two ways of changing administering institutions. In the first instance, the member needs to go to the new AFP and fill a transfer form. In the second instance, the member can ask the transfer of the Administrator via Internet service. Additionally, the members can transfer their balance between the three funds. In this case, the members must sign an agreement with the Administrator of the funds.

214. In Poland, to change administering institution or portfolio, it is necessary to do so via a traditional letter in all the systems (OFE, PPE, IKE).

215. In Russia, to change administering institution the insured person has to fill an application and submit it to the PFR in case if he/she changes the PFR for an NPF or vice a verse and sign new contract and inform the PFR in case he/she changes the NPF. To select new asset manager or switch between portfolios the insured person should fill an application and submit it to the PFR.

216. In South Africa, this differs from fund and administrator and is not regulated.

217. In the Slovak Republic, the administering institution can be changed by concluding a new agreement. It is not possible via telephone call, traditional letter or via Internet. The portfolio can be changed by amending the agreement. It is not possible via telephone call, traditional letter or via Internet.

218. In Turkey, requests for the change of portfolio or the pension company (administering institution) may be submitted through the written process, and through the call-centre. Currently, these requests cannot be submitted through the Internet; however, this option is expected to be available with the start of the recently regulated "digital signature" system. Requests for the change of portfolio should be submitted at least 5 working days prior to the date on which the member wishes the change to occur.

Table 14

\begin{tabular}{|c|c|c|}
\hline Country & Changing of administrative institution & Changing of portfolio \\
\hline Australia & Document describing the transaction. & Call center, Internet. \\
\hline Chile & Demand of transfer. & Demand of transfer. \\
\hline Czech Republic & Transfer form. & $\mathrm{n} / \mathrm{a}$. \\
\hline Estonia & Corresponding form. & $\begin{array}{l}\text { It must be submitted by corresponding form in: } \\
\text { bank offices, insurance companies, internet } \\
\text { banks (by password) and in Central Register of } \\
\text { Securities website. }\end{array}$ \\
\hline Hong Kong (China) & MPF, ORSO: n/a . & MPF, ORSO: Internet, fax, mail. \\
\hline Hungary & $\begin{array}{l}\text { (Changing of pension fund by) letter, transfer } \\
\text { form. }\end{array}$ & $\begin{array}{l}\text { It depends on the pension funds' rules (letter, } \\
\text { email, call center). }\end{array}$ \\
\hline Latvia & Demand of transfer. & Demand of transfer. \\
\hline Mexico & Demand of transfer. & Demand of transfer. \\
\hline Peru & Demand of transfer and Internet. & Demand of transfer. \\
\hline
\end{tabular}


OECD Working Paper on Insurance and Private Pensions

\begin{tabular}{|l|l|l|}
\hline Poland & Traditional letter. & Traditional letter. \\
\hline Russia & Application form. & Application form \\
\hline Slovak Republic & $\begin{array}{l}\text { By concluding a new agreement, but not } \\
\text { possible via call, traditional letter, Internet. }\end{array}$ & $\begin{array}{l}\text { By concluding a new agreement, but not } \\
\text { possible via call, traditional letter, Internet. }\end{array}$ \\
\hline South Africa & $\begin{array}{l}\text { It depends on the pension fund administrators' } \\
\text { rules. }\end{array}$ & $\begin{array}{l}\text { It depends on the pension fund administrators' } \\
\text { rules. }\end{array}$ \\
\hline Turkey & Call center, traditional letter. & Call center, traditional letter. \\
\hline
\end{tabular}

219. Thus, it can be concluded that, in some countries, (like Chile, Poland, the Slovak Republic and Russia) the portfolio can be changed in a traditional way (letter or application form). In other countries (like Australia, Hong-Kong (China) and Turkey) new alternatives (internet, fax or call centre) can also be used.

\section{Statistical information on some key issues in selected countries}

220. The issues presented in this chapter are not exhaustive, but they aim to provide some information on current practise.

221. The first part of this chapter will focus on the weight of all plans or funds that offer choice of administering institution, product or portfolio.

\section{Number of administering institutions, products and portfolios that allow individual choice}

222. In Australia, 716 entities (from 1786) offer investment choice.

223. In the mandatory pension plan in Chile, there are six administrator funds companies and each of them manages five investment portfolios.

224. In Estonia, six pension fund management companies received licenses to hold second-pillar pension alternatives, and 15 funds (portfolio) were registered.

225. In Hungary, there are only five funds from the 82 voluntary funds, which provide this option. The rest provide a single portfolio for all fund members.

226. In Ireland, each owner of a PRSA has the right to choose their product. Currently there are 53 PRSA products spread between Standard and non- Standard products on offer from 10 providers.

227. In Italy, there are 602 pension funds. Most of them are pre-existing pension funds (470), 43 are closed-end pension funds and 86 are open pension funds. Open pension funds offer individuals the choice between 3-5 portfolio options, with different risk profiles. Closed-end pension funds offers on average between 3-4 portfolio options, similar to those of open pension funds.

228. In Latvia, on 31 December 2004, the eight private investment management companies and the State Treasury (State asset manager) offered a total of 19 investment plans to participants in the Statefunded pension scheme

229. In Mexico, fifteen AFORES (pension fund management companies) operate in the mandatory pension system. Each of them offers to their members two investment portfolios. 
230. Currently, there are five AFPs (pension fund management companies) in the mandatory pension system in Peru. Each AFP manages 3 different funds, with different investment alternatives.

231. In Slovakia, under mandatory pension plans there are 8 administering institutions (PAMC), each PAMC operates 3 funds with different investment portfolios. (The supplementary pension plan is starting in 2006, so there is no relevant data.)

232. In Turkey, (as of September, 2005) the number of pension plans are 879, and there are 91 pension mutual funds (portfolio). It should be noted, that in Turkey all the plans provide the choice of institution and portfolio.

Table 15

\begin{tabular}{|c|c|}
\hline Country & $\begin{array}{l}\text { The number of all plans or funds that provide for choice of administering } \\
\text { institution, product and portfolio }\end{array}$ \\
\hline Australia & 716 entities (from 1786) offer investment choice. \\
\hline Chile & $\begin{array}{l}\text { Mandatory pension pension plan: } 6 \text { administering institution, each manages } 5 \\
\text { funds. }\end{array}$ \\
\hline Estonia & $\begin{array}{l}\text { Mandatory pension plan: six pension fund management companies - } 15 \\
\text { pension funds. }\end{array}$ \\
\hline Hungary & 5 voluntary pension funds from 82 offer portfolio choice. \\
\hline Ireland & PRSA: 10 providers - 53 products. \\
\hline Italy & $\begin{array}{l}\text { There are } 602 \text { pension funds. } 470 \text { are pre-existing pension funds, } 43 \text { are } \\
\text { closed-end pension funds and } 86 \text { are open pension funds. }\end{array}$ \\
\hline Latvia & $\begin{array}{l}\text { The } 8 \text { private asset management companies and the State Treasury offered a } \\
\text { total of } 19 \text { investment plans. }\end{array}$ \\
\hline Mexico & $\begin{array}{l}\text { Mandatory pension pension plan: } 15 \text { administering institution (AFORE); each } \\
\text { manages } 2 \text { funds. }\end{array}$ \\
\hline Peru & $\begin{array}{l}\text { Mandatory pension pension plan: } 5 \text { administering institution (AFP), each } \\
\text { manages } 3 \text { funds. }\end{array}$ \\
\hline Russia & $\begin{array}{l}90 \text { non-state pension fund+ Sate pension fund, } 55 \text { private asset managers: } 62 \\
\text { investment portfolios. }\end{array}$ \\
\hline Slovak Republic & $\begin{array}{l}\text { Mandatory pension pension plan: } 8 \text { administering institution (PAMC), each } \\
\text { manages } 3 \text { funds. }\end{array}$ \\
\hline Turkey & 11 pension fund companies - 91 pension mutual funds. \\
\hline
\end{tabular}

\section{Active choice of portfolio}

233. There is only very limited information for active choice of portfolio.

234. By October 2002, once implemented the multifunds system in Chile, a total of 947 thousand affiliates (15 percent of total affiliates) had made an active choice of at least one of the five different funds offered by each AFP. By the end of June 2005, this number increased to around 2 million affiliates (28 per cent of total affiliates), which means an increase of 112 per cent in this period. Classifying by type of fund, (share of affiliates that have chosen specific type of funds over the total of affiliates that made an active choice for the period October 2002 - June 2005), the share of affiliates that have chosen those funds with higher equity exposure (Fund A) has risen from 6 per cent to 25 per cent, and from 16 per cent to 38 per 
cent for fund B. In the mid position, the Fund C, which has represented the largest share from the inception of the program, has fallen from 62 per cent to 29 per cent. On the other hand, the individual preferences for those funds with a higher proportion of fixed income securities (Fund D and E) have fallen slightly to 5 per cent and 4 per cent respectively. Thus in general terms, it is possible to observe a tendency of choosing those pension funds with higher risk, because they have achieved the highest yields since the inception of the multifunds.

235. By the end of 2004, about 424,000 people had applied for the Estonia second pillar funded pension plan, which amounted to 70 per cent of the labour force. Based on the results of the individual choice of investment portfolio, over two thirds of second pillar participants -75 per cent or 350,000 members- have chosen the pension fund with higher risk level, which invest up to 50 per cent of the funds assets in equities. Members who have chosen the pension fund with the medium risk level, which invest up to 25 per cent of assets into equities, represent 17 per cent. The rest have joined funds with no equity exposure.

236. In Italy, by the end of 2005, the private pension funds collect 2,203,757 members. Most of them (52 per cent) are in closed-end pension funds, 18 per cent in open pension funds and $30 \%$ in pre-existing pension funds. The default option is typically chosen by $75-90$ per cent of members.

237. By the end of $2004,633,685^{14}$ participants or 27 per cent of Latvian residents had joined the second-tier pension scheme. 52 per cent of all these participants joined the active pension plans (up to 30 per cent in variable income securities). 280,684 or 45 per cent of all State-funded pension scheme participants opted for conservative investment plans (no equity exposure). 76 per cent of all these participants joined the State Treasury Investment Plan. Finally, 4 per cent of participants opted for balanced investment plans (up to 30 per cent in variable income securities).

238. Once implemented the new investment scheme in the mandatory pension system in Mexico (January 2005), the two different investment portfolios were structured in the following way: from the total universe of workers, a total of 11,552,553 individual accounts started in the SIEFORE Basica 1, whereas 21,770,337 individual account started in the SIEFORE Basica 2 (with variable income). Until end of May 2005, the number of individual accounts in the SIEFORE Type 1 raised to 11,590,912, which means an increase of 0.3 per cent, whereas during the same period the SIEFORE Type 2 increased by 0.6 per cent, reaching 21,904,911 individual accounts.

239. In Slovakia, according to information provided by the Authority for Financial Markets, by the end of September 2005, around $1,000,000$ or 47 per cent of total eligible workers had opted for the capitalization pillar. From these members a high proportion has selected the growth fund (65.5 per cent), whilst a minimal proportion of workers have chosen the conservative fund ( 4.6 per cent). The members who have selected the balanced funds account for almost 30 per cent.

240. In Turkey, according to the legislation, 6 main types of Pension Mutual Funds have been defined in order to standardize the practices of the pension companies. These are the following: Income Funds, Growth Funds, Money Market Funds, Precious Metals Funds, Specialized Funds, Other Funds. The member can choose more than one pension mutual fund, usually the member chooses a composition from 3 different PMFs. The next chart will show the preferences related to the members' active choice- in the most of the cases, the Income funds seem to be the most popular alternative.

\footnotetext{
${ }^{14}$ This report incorporates data collected by the State Social Insurance Agency on State-funded pension scheme participants.
} 
Table 16 -The pension fund members' active choice based on the number of members in context of the listed funds in Turkey

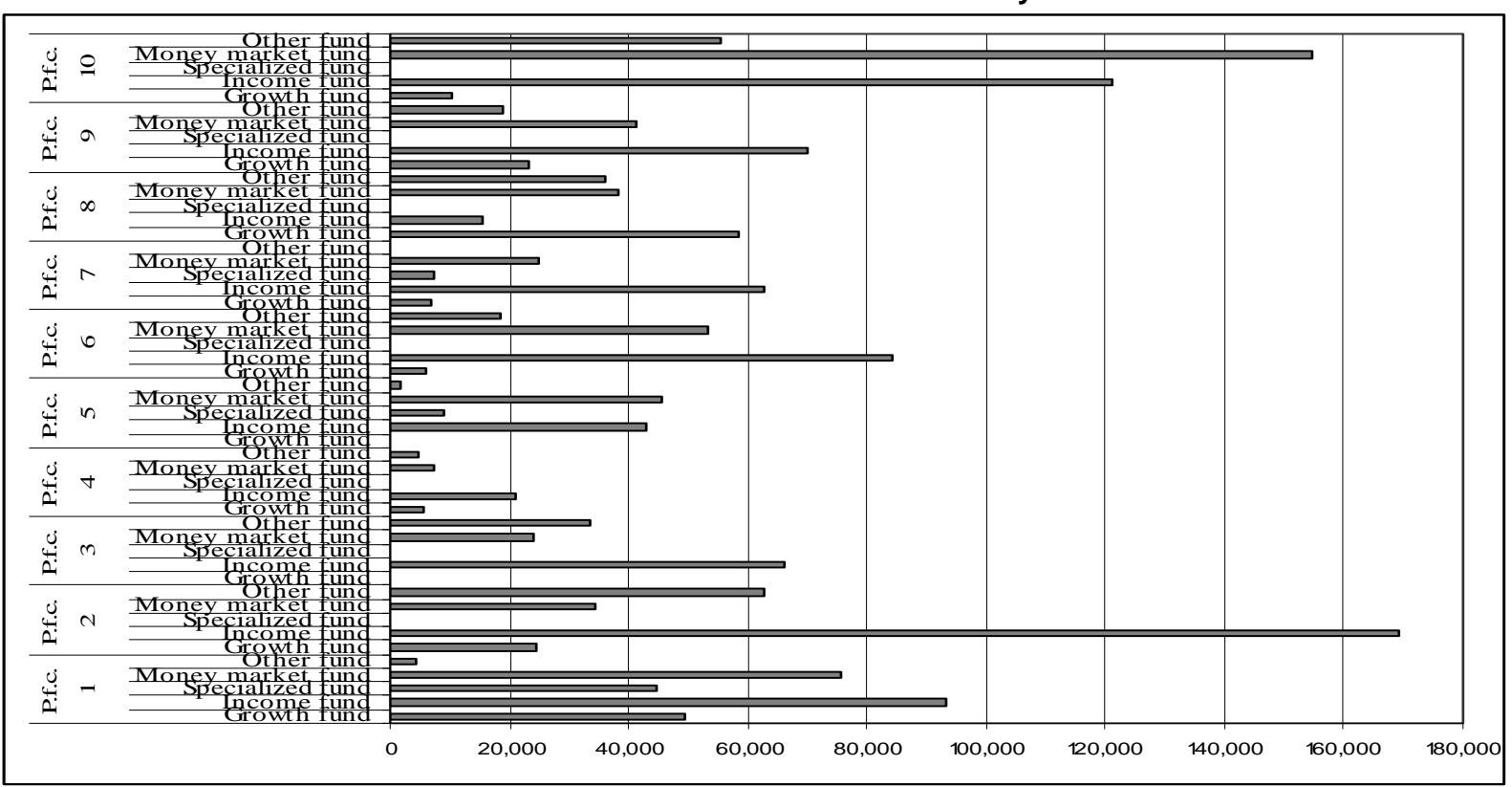

Source: The Undersecretariat of Treasury

\section{Asset allocation of default portfolio}

241. Regarding Table 13, there is default portfolio specified in Australia, Chile, Estonia, Latvia Hungary, Mexico, Peru and the Slovak Republic ${ }^{15}$. The next paragraphs intend to present some information related to the investment strategy of the default portfolio.

242. In Australia, not all superannuation entities are required to have a default investment strategy. Where there is no default strategy, the strategy of the largest option is reported (or the total entity where there is no investment choice). Anyway, the average default option for members that do not choose a specific portfolio is a Balanced option. In 2004, more than the half (54 per cent) of the total assets in case of default portfolio was shares.

Table 17-Asset allocation of default investment strategy in Australia (June 2004)

\begin{tabular}{|l|c|c|c|c|c|}
\hline & Corporate & Industry & $\begin{array}{l}\text { Public } \\
\text { sector }\end{array}$ & Retail & Total \\
\hline Australian shares & $36 \%$ & $35 \%$ & $35 \%$ & $30 \%$ & $33 \%$ \\
\hline International shares & $21 \%$ & $23 \%$ & $28 \%$ & $15 \%$ & $21 \%$ \\
\hline Listed property & $4 \%$ & $4 \%$ & $3 \%$ & $1 \%$ & $3 \%$ \\
\hline Unlisted property & $3 \%$ & $6 \%$ & $8 \%$ & $0 \%$ & $4 \%$ \\
\hline Australian fixed interest & $10 \%$ & $12 \%$ & $8 \%$ & $22 \%$ & $15 \%$ \\
\hline International fixed interest & $5 \%$ & $7 \%$ & $6 \%$ & $5 \%$ & $6 \%$ \\
\hline Cash & $7 \%$ & $5 \%$ & $8 \%$ & $7 \%$ & $7 \%$ \\
\hline Other & $14 \%$ & $9 \%$ & $4 \%$ & $19 \%$ & $12 \%$ \\
\hline Total & $100 \%$ & $100 \%$ & $100 \%$ & $100 \%$ & $100 \%$ \\
\hline
\end{tabular}

Source: Australian Prudential Regulation Authority

\footnotetext{
${ }^{15}$ There is no information is available, because mandatory pension plan was launched in January, 2005.
} 
243. In Chile, the default investment portfolio varies according to age; therefore the asset allocation for each default option is different. The default portfolio for men and women below 35 years old is the fund B; for men between 36 and 55 and women between 36 and 50 is the fund C; and those who are older than 56 in the case of men and 51 in the case of women is the fund D.

Table 18 -Asset allocation of default investment portfolio in Chile (June 2005)

\begin{tabular}{|l|c|c|c|}
\hline & Fund B & Fund C & Fund D \\
\hline Public Securities & $14.5 \%$ & $20.9 \%$ & $32.2 \%$ \\
\hline Financial Institutions & $26.6 \%$ & $28.9 \%$ & $33 . \%$ \\
\hline Companies & & & \\
\hline - Shares & $17.3 \%$ & $13.2 \%$ & $8.9 \%$ \\
\hline - Bonds and others & $7.3 \%$ & $10.9 \%$ & $9.9 \%$ \\
\hline Foreign Investment & $34.2 \%$ & $25.8 \%$ & $15.0 \%$ \\
\hline
\end{tabular}

244. In Mexico, the portfolio established by default varies according to the age. The SIEFORE Basica 2 was established as the default option for all workers; except for those who are 56 or older, whose default option is the SIEFORE Basica 1.

Table 19 -Asset allocation of default investment portfolio in Mexico (June 2005)

\begin{tabular}{|l|c|c|}
\hline & SIEFORE 1 & SIEFORE 2 \\
\hline Public Securities & $82.5 \%$ & $83.0 \%$ \\
\hline Financial Institutions (fixed income instruments ) & $4.1 \%$ & $8.4 \%$ \\
\hline Companies (fixed income instruments) & $9.3 \%$ & $4.0 \%$ \\
\hline Foreign Investment & $0 \%$ & $0 \%$ \\
\hline Variable Income Instruments & $0 \%$ & $1 \%$ \\
\hline Local governments and decentralized institutions & $4.1 \%$ & $3.6 \%$ \\
\hline
\end{tabular}

Source: CONSAR

245. In the mandatory pension system in Peru, there is not only one default investment portfolio for all the members. The default option for members younger than 60 years old is the mixed Fund (with more relative participation of equities), whilst the default option for members older than 60 years is the conservative Fund. (The multifunds system will start in November 2005)

246. In Estonia, the conservative alternative is the default option, which means 100 per cent of assets invested in fixed-income instruments. (Thus to invest in shares is not allowed).

247. In Hungary, if the individual does not choose an alternative, two of the pension funds allocate her or him to the one that has the largest number of members that made active choices. At the other pension fund companies, when the member joins the fund, the individual has to choose a specific portfolio alternative. It is not possible to join the fund otherwise.

248. In Latvia and Slovakia, the conservative investment portfolio is the default option, which means all the assets are invested only in fixed-income instruments.

\section{Changing of portfolio}

249. In Hungary, the number of changes made to portfolios shows a significant decline in 2004, which indicate a lack of motivation with regard to making active investment choices through changes in the investment portfolio. Overall, this evidence suggests that the portfolio choice system managed by voluntary pension funds in Hungary was not very popular with either the pension funds or the plan members. 
250. According to September 2005 data, in Turkey, among the total number of 608,000 pension contracts, approximately 30,000 portfolio change occurred. Thus, there has been a change of portfolio in 4.93 per cent of the pension contracts.

\section{Management and switching fees}

251. Fees concerning changing portfolio are called switching fees. These are special fees in the sense that they arise from a decision taken by members. Whilst in some cases they are linked to asset size, whilst in other cases they are made up of a fixed fee.

252. In Australia, First State Super (a public sector scheme) permits one free portfolio switch per year, with additional switches costing ${ }^{16} 18.5$ US $\$$ each.

253. In Chile, for the services they provide, AFPs may charge monthly a fixed commission, which currently ranges from US\$ 0 to US\$1.3, and a variable commission expressed as a percentage of the workers taxable income, which currently ranges from 2.23 per cent to 2.48 per cent of that income.

Table 20 -Management fees in Chile (October, 2005)

\begin{tabular}{|l|c|c|}
\hline & $\begin{array}{l}\text { Fixed Commission } \\
\text { (US\$) }\end{array}$ & $\begin{array}{l}\text { Variable } \\
\text { Commission }(\%)\end{array}$ \\
\hline AFP 1 & 1.26 & 2.42 \\
\hline AFP 2 & 0 & 2.48 \\
\hline AFP 3 & 0.59 & 2.23 \\
\hline AFP 4 & 1.27 & 2.55 \\
\hline AFP 5 & 0.72 & 2.25 \\
\hline AFP 6 & 1.28 & 2.29 \\
\hline
\end{tabular}

254. Regarding switching fees in Hungary, three of the five voluntary pension funds allow individuals to change their portfolio free of charge the first time. Thereafter, at three voluntary pension funds a small fixed fee (1.93 US\$-24.1US\$) has to be paid to change portfolio, at the other two voluntary pension fund $\mathrm{s}$ the fee is linked to the assets ( 0.05 per cent or 0.1 per cent of the assets).

Table 21-Costs ${ }^{17}$ of changing portfolio at the five voluntary fund in Hungary (2005)

\begin{tabular}{|l|l|}
\hline Pension fund 1 & $\begin{array}{l}0.05 \% \text { of the assets of the member, but 4.82 USD minimum and 24.1US\$ } \\
\text { maximum. First time is not free. }\end{array}$ \\
\hline Pension fund 2 & Maximum 0.01\% of the assets of the member But the first time is free. \\
\hline Pension fund 3 & 9.64 US\$ maximum /occasion. But the first time is free. \\
\hline Pension fund 4 & 1.93 US\$ /occasion. But the first time is free. \\
\hline Pension fund 5 & 11.08 US\$ /occasion \\
\hline Source: HFSA
\end{tabular}

255. In Estonia, if the individuals want to transfer the assets to new alternative, it is necessary also to pay unit issue and redemption fees. The redemption fee is the same (1 per cent) in case of each alternative at each pension fund management companies. The unit issue fees in the different fund alternatives and fund management companies. Only one pension fund management company uses different issue fees for the various portfolio alternatives. On the other hand, the issue fees for a given alternative vary significantly between fund managers.

\footnotetext{
16 The exchange rate: 1.35 AUS\$/US\$.

${ }^{17}$ The exchange rate: 207.5 HUF/US\$.
} 
Table 22-Fees at the pension fund management companies in Estonia (2004)

\begin{tabular}{|l|c|c|c|c|c|}
\hline & $\begin{array}{c}\text { Management } \\
\text { Company 1 }\end{array}$ & $\begin{array}{c}\text { Management } \\
\text { Company 2 }\end{array}$ & $\begin{array}{c}\text { Management } \\
\text { Company 3 }\end{array}$ & $\begin{array}{c}\text { Management } \\
\text { Company 4 }\end{array}$ & $\begin{array}{c}\text { Management } \\
\text { Company 5 }\end{array}$ \\
\hline Issue fee (\%) & $1.5 \%$ & $3 \%$ & $1,5 \%$ & $1 \%$ & $1 \%-2 \%$ \\
\hline Redemption fee (\%) & $1 \%$ & $1 \%$ & $1 \%$ & $1 \%$ & $1 \%$ \\
\hline Management fee (\%) & & & & & \\
\hline - Conservative fund & $1.2 \%$ & $0.75 \%$ & $1.19 \%$ & $1.45 \%$ & $1.38 \%-1.5 \%$ \\
\hline - Balanced fund & - & - & $1.45 \%$ & $1.75 \%$ & $1.63 \%$ \\
\hline - Progressive fund & $1.5 \%$ & $1.25 \%$ & $1.59 \%$ & $1.85 \%$ & $1.88 \%-2 \%$ \\
\hline
\end{tabular}

Source: Ministry of Finance

256. The asset managers in the Latvian State-funded Pension Scheme (SFPS) are allowed to charge fees for asset management. The fee is established as a percentage of average annual assets of the investment plan. Neither front load (entry), nor back load (exit) is allowed in the SFPC.

Table 23. : Fees and commission charged by each pension funds management company in Latvia (2004)

\begin{tabular}{|l|c|c|c|}
\hline & \multicolumn{3}{|c|}{ Fees per year of average assets (\%) } \\
\hline & Conservative & Balanced & Active \\
\hline State Treasury & $0.75 \%$ & & \\
\hline Asset manager 1 & $1.40 \%$ & - & $1.90 \%$ \\
\hline Asset manager 2 & $1.46 \%$ & - & $1.71 \%$ \\
\hline Asset manager 3 & $1.28 \%$ & - & $1.68 \%$ \\
\hline Asset manager 4 & $1.38 \%$ & $1.45 \%$ & $1.50 \%$ \\
\hline Asset manager 5 & $1.25 \%$ & - & $1.50 \%$ \\
\hline Asset manager 6 & - & $1.15 \%-1.50 \%$ & $1.7 \%$ \\
\hline Asset manager 7 & $1.38 \%$ & - & $1.63 \%$ \\
\hline
\end{tabular}

Source: State Social Insurance Agency.

257. In Slovakia, by November 2005 all PAMCs charge the up-front fee of 1 per cent of the amount of monthly contribution. This commission is standard for all members and for all the funds managed by a single PAMC. In terms of management fees as a percentage of the monthly assets, only two PAMCs do not charge this fee. The other 6 PAMCs charge a fee that varies between 0.07 per cent to 0.08 per cent.

Table 24. : Fees and commission charged by each PAMC in Slovakia (2005)

\begin{tabular}{|l|l|l|l|l|l|l|l|l|}
\hline PAMC & PAMC 1 & PAMC 2 & PAMC 3 & PAMC 4 & PAMC 5 & PAMC 6 & PAMC 7 & PAMC 8 \\
\hline Up-front fee & $1 \%$ & $1 \%$ & $1 \%$ & $1 \%$ & $1 \%$ & $1 \%$ & $1 \%$ & $1 \%$ \\
\hline $\begin{array}{l}\text { Management } \\
\text { fee }\end{array}$ & $\begin{array}{l}0.07 \%- \\
\text { in all } \\
\text { funds }\end{array}$ & $\begin{array}{l}0 \%-\text { in } \\
\text { all funds }\end{array}$ & $\begin{array}{l}0 \% \text { in all } \\
\text { funds }\end{array}$ & $\begin{array}{l}0.08 \%-\text { in } \\
\text { all funds }\end{array}$ & $\begin{array}{l}0 \%-\text { in } \\
\text { conservative } \\
\text { fund } \\
0.07 \% \text { in } \\
\text { balance and } \\
\text { growth fund }\end{array}$ & $\begin{array}{l}0.07 \%-\text { in } \\
\text { all funds }\end{array}$ & $\begin{array}{l}0.08 \%- \\
\text { in all } \\
\text { funds }\end{array}$ & $0.08 \%$ \\
\hline
\end{tabular}


Appendix 1.- Questionnaire

\title{
OECD $\ll \bigcirc$ OCDE
}

ORGANISATION FOR ECONOMIC

ORGANISATION DE COOPÉRATION ET

CO-OPERATION AND DEVELOPMENT

DE DÉVELOPPEMENT ÉCONOMIQUES

\begin{abstract}
DIRECTION DES AFFAIRES FINANCIÈRES ET DES ENTREPRISES
DIRECTORATE FOR FINANCIAL AND ENTERPRISE AFFAIRS
\end{abstract}

\section{QUESTIONNAIRE-}

Investment choice by members in private pension plans

\footnotetext{
We would kindly like to ask you to answer the following questions by 30 September 2005 at the latest.

Should you require any further assistance in order to fill in the questionnaire, please do not hesitate to contact Edina Rozinka: [Tel: +33 1452415 24, Fax: +33 1452478 52, Email: edina.rozinka@ oecd.org] or Mr. Waldo Tapia [Tel: +33 1452475 26, Fax: +33 1443063 28, Email: waldo.tapia@oecd.org]
} 


\section{Background}

This questionnaire is the follow-up and extension of the document "Survey of Investment Choice by Pension Fund Members" (DAF/AS/PEN/WD(2005)7) discussed at the November 2005 meeting of the Working Party on Private Pensions.

It is being sent to selected OECD countries that volunteered to provide further information on this topic. It will also be sent to selected countries in Latin America and Asia that have introduced investment choice in mandatory or voluntary pension systems.

The questionnaire covers both occupational (defined contribution only) and personal pension plans. Mandatory arrangements will be treated separately from voluntary ones, especially where they operate under social security arrangements.

\section{Format of responses}

Delegates are invited to respond to the questions below and to provide additional information relevant to the discussion, such as existing reports on the subject focusing on the country's experience with investment choice. Responses may be in the form of a country report that covers the issues raised by the questionnaire.

\section{Information availability}

In countries where there is a large number of pension plans, aggregate data on investment choices, default options, costs, frequency of choice, and other related issues may not be available. As an alternative, Delegates are invited to consider sending the questionnaire to selected pension plans or assisting the Secretariat in identifying the plans in the country that offer investment choice so that the Secretariat can follow-up directly with them. 
I. Information on legal framework of member choice

Please provide separate responses for each category of pension plans (mandatory occupational defined contribution pension plan, voluntary occupational defined contribution pension plan, mandatory personal pension plan, voluntary personal pension plan) that exists in the country.

\section{GENERAL INFORMATION}

1. Are pension plans required by law/regulation to offer return or benefit guarantees? If yes, please state the level of the minimum or fixed return/benefit and how often it is revised.

2. Please state whether members of occupational DC plans can switch to a personal pension plan while continuing working for the plan sponsor of the occupational plan. Is the plan sponsor required to contribute to the personal pension plan chosen by the member?

3. Please specify whether the plans can allow members to obtain pre-retirement distributions (withdrawals) and whether they can offer loans to members or other ancillary benefits. Are there tax penalties for early withdrawals?

4. Please specify whether the employer must or may contribute to these plans and what are the tax limits on the employer's and member's contribution?

5. Does the law/regulation specify the type of fees that providers can charge (e.g. entry, exit fees, ongoing fees), their structure (e.g. on contributions, on assets, on performance), and their level (e.g. $1 \%$ of assets under management)?

\section{CHOICE OF ADMINISTERING ENTITY}

6. Please specify whether only certain institutions are authorized to administer these pension plans during both the contribution and drawdown phases (e.g. pension fund, pension fund administrator, life insurance company, bank, investment company, etc) and whether there is a maximum number of institutions from which members may choose. In the case of occupational DC plans, please state if only the plan sponsor can choose the administering institution.

7. Please specify whether there are limits in the frequency of switching between administering institutions by pension plan members.

8. Does the legislation specify the default institution for members that do not make an active choice? If yes, what is the default institution?

\section{CHOICE OF PRODUCT}

9. Please specify whether only certain products can be used as financing vehicles (e.g. pension fund, life insurance policies - such as unit-linked products and deferred annuities-, bank products - such as deposits, structured bank products offering capital protection, mutual/investment funds, etc) during both the contribution and drawdown phases and whether there is a maximum number of products from which members may choose. In the case of occupational DC plans, please state if only the plan sponsor can choose the product.

10. Please specify whether there are limits in the frequency of switching between products by pension plan members. 
11. Does the legislation specify the default product for members that do not make an active choice? If yes, what is the default product?

\section{CHOICE OF PORTFOLIO}

12. Please specify whether members can exert portfolio choice within each product during both the contribution and drawdown phases, whether there is a maximum of portfolios from which members may choose and whether the types of portfolio are regulated (e.g. a mixed portfolio, a conservative portfolio, and a capital protection fund). If specific quantitative limits by asset class (e.g. equities, bonds, real estate, derivative products) are set for each portfolio, please state these limits.

13. Please specify whether there are limits in the frequency of switching between portfolios by pension plan members

14. Does the legislation specify the default portfolio for members that do not make an active choice? If yes, what is the default portfolio?

II. Data on actual member choices

Please provide separate responses for each category of pension plans (mandatory occupational defined contribution pension plan, voluntary occupational defined contribution pension plan, mandatory personal pension plan, voluntary personal pension plan), where member choice exists.

15. Please list the number or percentage of all plans (or funds) - even approximately - that provide for choice of administering institution, product and portfolio.

16. Please provide the number or percentage of members that actively chose institution, product and portfolio as well as a breakdown of the choices made by members by type of institution, product and portfolio in 2002, 2003 and 2004.

17. Please provide the amount of the invested assets in each of the different institutions, products and portfolios chosen actively by members in 2002, 2003 and 2004.

18. Please describe the investment strategy or asset allocation of each portfolio choice in 2002, 2003 and 2004 according to broad assets classes: domestic state bonds, domestic corporate bonds, foreign state bonds, domestic equities, foreign equities, etc.

19. What is the average default option for members that do not choose a specific institution, product or portfolio? If a breakdown of default options is available please provide it.

20. Please explain how members may change (i) the administering institution, (ii) the product, (iii) the portfolio. e.g. by traditional letter, through call-center, in internet by password....

21. What was the average cost (please state currency) to changing (i) the administering institution, (ii) the product, (iii) the portfolio in 2002, 2003 and 2004?

22. How many or what percentage of members switched (i) the administering institution, (ii) the product, (iii) the portfolio in 2002, 2003 and 2004? 
DAF/AS/PEN/WD(2005)7/REV2

Appendix 2 -Member choice of administrative institution / pension fund company, product ${ }^{18}$ and portfolio by the covered pension plans

\begin{tabular}{|c|c|c|c|c|}
\hline COUNTRY & PENSION PLAN & $\begin{array}{l}\text { CHOICE OF ADMINISTRATIVE } \\
\text { INSTITUTION/PENSION FUND }\end{array}$ & CHOICE OF PRODUCT & CHOICE OF PORTFOLIO \\
\hline Australia & $\begin{array}{l}\text { Mandatory } \\
\text { occupational and } \\
\text { personal pension plans. }\end{array}$ & $\begin{array}{l}\text { Yes, under the choice of fund } \\
\text { legislation that commenced on } 1 \\
\text { July } 2005 \text {, employers have must } \\
\text { pay the mandatory contributions to } \\
\text { a fund chosen by the employee. }\end{array}$ & $\begin{array}{l}\text { No in occupational plans. } \\
\text { Yes in personal pension plans, } \\
\text { contributions must either be paid into a } \\
\text { complying regulated superannuation } \\
\text { fund (generally) operated as a trust by a } \\
\text { trustee, or into a Retirement Savings } \\
\text { Account. } \\
\text { The rollover amounts may be paid into } \\
\text { a superannuation fund or specialist } \\
\text { rollover funds known as Approved } \\
\text { Deposit Funds (ADFs) or to a deferred } \\
\text { annuity product offered by a life } \\
\text { insurance company. Funds may be } \\
\text { unitized or unit-linked or a crediting } \\
\text { rate may be applied. Superannuation } \\
\text { funds may invest into mutual funds as } \\
\text { well as directly invest. }\end{array}$ & $\begin{array}{l}\text { Yes in case of superannuation funds. } \\
\text { No in case of Retirement Savings } \\
\text { Accounts, as they are capital } \\
\text { guaranteed (there is no portfolio choice } \\
\text { available). }\end{array}$ \\
\hline
\end{tabular}

\footnotetext{
${ }^{18}$ In the contribution phase.
} 
DAF/AS/PEN/WD(2005)7/REV2

\begin{tabular}{|c|c|c|c|c|}
\hline COUNTRY & PENSION PLAN & $\begin{array}{c}\text { CHOICE OF } \\
\text { ADMINISTRATIVE } \\
\text { INSTITUTION/PENSION FUND }\end{array}$ & CHOICE OF PRODUCT & CHOICE OF PORTFOLIO \\
\hline \multirow[t]{2}{*}{ Chile } & $\begin{array}{l}\text { Mandatory pension } \\
\text { plan. }\end{array}$ & Yes. & No. & $\begin{array}{l}\text { Yes, the members can choice among } \\
\text { five different investment choices. } \\
\text { Additionally, members can allocate } \\
\text { their contributions between two } \\
\text { different funds within one AFP, in } \\
\text { whatever proportion they want, which } \\
\text { allow to achieve a closer approximation } \\
\text { to the risk return preference of each } \\
\text { member. The only limitation is for } \\
\text { pensioners, male members over } 55 \text { year } \\
\text { old and female members over } 50 \text { year } \\
\text { old. }\end{array}$ \\
\hline & Voluntary pension plan. & Yes. & $\begin{array}{l}\text { Yes, there are products offered by } \\
\text { banks, life assurance companies, } \\
\text { mutual funds and others. }\end{array}$ & $\begin{array}{l}\text { Yes, the members can choice among } \\
\text { five different investment choices. }\end{array}$ \\
\hline Czech Republic & $\begin{array}{l}\text { Personal pension plan } \\
\text { (Supplementary } \\
\text { pension insurance) }\end{array}$ & Yes. & No. & No. \\
\hline Estonia & $\begin{array}{l}\text { Individual mandatory } \\
\text { funded pension plan (II } \\
\text { pillar). }\end{array}$ & Yes. & No. & $\begin{array}{l}\text { Yes, members may choose among the } \\
\text { (three) types of investment portfolio } \\
\text { offered by pension fund manager, } \\
\text { which differ in the investment strategy. }\end{array}$ \\
\hline
\end{tabular}


DAF/AS/PEN/WD(2005)7/REV2

\begin{tabular}{|c|c|c|c|c|}
\hline COUNTRY & PENSION PLAN & $\begin{array}{l}\text { CHOICE OF ADMINISTRATIVE } \\
\text { INSTITUTION/PENSION FUND }\end{array}$ & CHOICE OF PRODUCT & CHOICE OF PORTFOLIO \\
\hline & $\begin{array}{l}\text { Voluntary } \\
\text { pension plan } \\
\text { pillar). }\end{array}$ & $\begin{array}{l}\text { Yes, the supplementary funded } \\
\text { pension system is based on each } \\
\text { person's voluntary decision to start } \\
\text { saving either by contributions to a } \\
\text { voluntary pension fund or by } \\
\text { entering into a respective insurance } \\
\text { contract on the supplementary } \\
\text { funded pension with a life } \\
\text { insurance company. }\end{array}$ & $\begin{array}{l}\text { Yes, there are three different pension } \\
\text { products: pension funds, pension } \\
\text { insurance with guaranteed interest } \\
\text { (different options like lifetime pension } \\
\text { insurance with life insurance, term } \\
\text { pension insurance with life insurance) } \\
\text { and pension insurance with investment } \\
\text { risk (unit-linked, investment insurance, } \\
\text { fund contract, growth portfolio). }\end{array}$ & Yes. \\
\hline \multirow{2}{*}{ Hong Kong (China) } & $\begin{array}{l}\text { Mandatory } \\
\text { occupational } \\
\text { Schemes). }\end{array}$ & $\begin{array}{l}\text { No, the choice of trustee rests with } \\
\text { the employer. }\end{array}$ & No. & $\begin{array}{l}\text { Yes, but members who are employees } \\
\text { choose from the fund options of the } \\
\text { MPF scheme chosen by their } \\
\text { employers. Self employed persons can } \\
\text { choose the scheme and the fund option. } \\
\text { The portfolio choice rests with the fund } \\
\text { manager of the fund option. }\end{array}$ \\
\hline & $\begin{array}{l}\text { Voluntary occupational } \\
\text { (ORSO Schemes) } \\
\text { pension plans. }\end{array}$ & $\begin{array}{l}\text { No, the choice of administrative } \\
\text { entity rests with the employer. }\end{array}$ & No. & $\begin{array}{l}\text { Yes, but no statutory restrictions on } \\
\text { whether the plan sponsor or the } \\
\text { employees are responsible for choosing } \\
\text { fund options. The portfolio choice rests } \\
\text { with the fund manager of the fund } \\
\text { option. }\end{array}$ \\
\hline Hungary & $\begin{array}{l}\text { Voluntary pension } \\
\text { plan. }\end{array}$ & $\begin{array}{l}\text { Yes, the member can choose the } \\
\text { pension fund.. }\end{array}$ & No. & $\begin{array}{l}\text { Yes, but only in case of } 5 \text { voluntary } \\
\text { pension fund. }\end{array}$ \\
\hline
\end{tabular}


DAF/AS/PEN/WD(2005)7/REV2

\begin{tabular}{|c|c|c|c|c|}
\hline COUNTRY & PENSION PLAN & $\begin{array}{l}\text { CHOICE OF ADMINISTRATIVE } \\
\text { INSTITUTION/PENSION FUND }\end{array}$ & CHOICE OF PRODUCT & CHOICE OF PORTFOLIO \\
\hline \multirow[t]{2}{*}{ Ireland } & $\begin{array}{l}\text { Personal retirement } \\
\text { Saving Account-PRSA. }\end{array}$ & $\begin{array}{l}\text { Yes, but generally the employer, who } \\
\text { selects the PRSA provider. If the } \\
\text { employees do not favour the provider } \\
\text { designated by the employer, they can } \\
\text { choose an alternative provider from } \\
\text { amongst the approved providers but } \\
\text { will have to make their own } \\
\text { arrangements regarding payment of } \\
\text { contributions. }\end{array}$ & No. & $\begin{array}{l}\text { Yes, if the contributor opts for the } \\
\text { Default Investment Strategy (DIS) then } \\
\text { that is the portfolio mix which will be } \\
\text { used. If someone enter a PRSA with } \\
\text { less than } 3 \text { years to retirement the DIS } \\
\text { would typically have that person } \\
\text { invested in } 30 \% \text { equity and } 70 \% \text { fixed } \\
\text { interest or if the person had } 7 \text { yrs to go } \\
\text { it might be } 50: 50 \text { or if the person had } \\
\text { longer than } 7 \text { years it might be } 100 \% \\
\text { managed funds with a constant } \\
\text { percentage reduction towards fixed } \\
\text { income as retirement approaches. All } \\
\text { of this information is known to the } \\
\text { contributor and he/she can opt out of } \\
\text { DIS at intervals which gives } \\
\text { investment choices. }\end{array}$ \\
\hline & $\begin{array}{l}\text { Occupational pension } \\
\text { plan. }\end{array}$ & $\begin{array}{l}\text { Yes, but it is the employer who will } \\
\text { appoint the administering institution } \\
\text { and the range of advisers involved } \\
\text { with the plan ie lawyers, actuaries, } \\
\text { accountants, investment managers. }\end{array}$ & No. & $\begin{array}{l}\text { Yes, trust deeds are allowed to confer } \\
\text { an option for the member to determine } \\
\text { the manner in which his/her } \\
\text { contributions are invested, perhaps } \\
\text { from a range of funds chosen by the } \\
\text { trustees. }\end{array}$ \\
\hline Israel & $\begin{array}{l}\text { Voluntary occupational } \\
\text { defined contributions } \\
\text { pension plans and } \\
\text { voluntary personal } \\
\text { pension plans. } \\
\end{array}$ & Yes. & Yes. & $\begin{array}{l}\text { Yes. Members can exert portfolio } \\
\text { choice within each product, during the } \\
\text { contribution phase. }\end{array}$ \\
\hline Italy & $\begin{array}{l}\text { Occupational pension } \\
\text { funds (closed and open } \\
\text { pension funds) }\end{array}$ & $\begin{array}{l}\text { Yes. An agreement must be signed } \\
\text { between the government board of the } \\
\text { pension fund and the asset manager. }\end{array}$ & Yes. & Yes. \\
\hline
\end{tabular}


DAF/AS/PEN/WD(2005)7/REV2

\begin{tabular}{|c|c|c|c|c|}
\hline COUNTRY & PENSION PLAN & $\begin{array}{l}\text { CHOICE OF ADMINISTRATIVE } \\
\text { INSTITUTION/PENSION FUND }\end{array}$ & CHOICE OF PRODUCT & CHOICE OF PORTFOLIO \\
\hline Latvia & $\begin{array}{l}\text { Mandatory pension } \\
\text { plan. }\end{array}$ & Yes. & No. & Yes. \\
\hline Mexico & $\begin{array}{l}\text { Mandatory pension } \\
\text { plan. }\end{array}$ & Yes. & No. & $\begin{array}{l}\text { Yes, the members are allowed to } \\
\text { choose only one of the (two) funds } \\
\text { offered by each AFORE. }\end{array}$ \\
\hline \multirow{2}{*}{ Peru } & $\begin{array}{l}\text { Mandatory pension } \\
\text { plan. }\end{array}$ & Yes & No & $\begin{array}{l}\text { Yes, the members are allowed to } \\
\text { choose only one of the (three) funds } \\
\text { offered by each AFPs. }\end{array}$ \\
\hline & $\begin{array}{l}\text { Voluntary pension } \\
\text { plan. }\end{array}$ & Yes. & $\begin{array}{l}\text { Yes, there are products offered by } \\
\text { banks, life assurance companies, } \\
\text { mutual funds and others. }\end{array}$ & $\begin{array}{l}\text { Yes, the members can choice among } \\
\text { three different portfolios. }\end{array}$ \\
\hline \multirow{3}{*}{ Poland } & $\begin{array}{l}\text { Mandatory personal } \\
\text { plans (OFE). }\end{array}$ & Yes. & No. & No. \\
\hline & $\begin{array}{l}\text { Voluntary } \\
\text { occupational plan }\end{array}$ & Yes. & No. & $\begin{array}{l}\text { Choice of portfolio is up to the PPE } \\
\text { statute. }\end{array}$ \\
\hline & $\begin{array}{l}\text { Voluntary personal } \\
\text { pension plan (IKE). }\end{array}$ & Yes. & No. & $\begin{array}{l}\text { Choice of portfolio is up to the IKE } \\
\text { statute. }\end{array}$ \\
\hline Russia & $\begin{array}{l}\text { Funded mandatory } \\
\text { pension plan. }\end{array}$ & $\begin{array}{l}\text { Yes, the right to choose an asset } \\
\text { manager or pension fund is available } \\
\text { to participants, who have not reached } \\
\text { the age five year less than the normal } \\
\text { pensionable age. }\end{array}$ & No. & $\begin{array}{l}\text { Yes, but unlike on case of direct } \\
\text { choice of asset manager, the } \\
\text { participant, by choosing a private } \\
\text { pension fund, will trust the fund to } \\
\text { choose an asset manager, which may } \\
\text { offer several investment portfolio. }\end{array}$ \\
\hline
\end{tabular}


DAF/AS/PEN/WD(2005)7/REV2

\begin{tabular}{|c|c|c|c|c|}
\hline COUNTRY & PENSION PLAN & $\begin{array}{l}\text { CHOICE OF ADMINISTRATIVE } \\
\text { INSTITUTION/PENSION FUND }\end{array}$ & CHOICE OF PRODUCT & CHOICE OF PORTFOLIO \\
\hline \multirow{2}{*}{ Slovak Republic } & $\begin{array}{l}\text { Mandatory personal } \\
\text { pension plan. }\end{array}$ & Yes. & No. & $\begin{array}{l}\text { Yes, members may choose among the } \\
\text { (three) types of investment portfolio } \\
\text { offered by each PAMC, which differ } \\
\text { in the investment strategy. Member } \\
\text { can be only a member of one portfolio. }\end{array}$ \\
\hline & $\begin{array}{l}\text { Supplementary } \\
\text { voluntary personal } \\
\text { pension plan. }\end{array}$ & Yes. & No. & $\begin{array}{l}\text { Yes, members may choose among the } \\
\text { (two) types of investment portfolio } \\
\text { offered by each SPMC, which differ in } \\
\text { the investment strategy. }\end{array}$ \\
\hline South Africa & $\begin{array}{l}\text { Voluntary } \\
\text { occupational pension } \\
\text { plan (retirement fund). }\end{array}$ & $\begin{array}{l}\text { No, in the case of a new fund, the } \\
\text { plan sponsor (employer) will choose } \\
\text { the administrator, however after the } \\
\text { fund has commenced and a board of } \\
\text { trustees is in place it would be their } \\
\text { responsibility to appoint an } \\
\text { administrator to the fund. Members } \\
\text { will only have the option of another } \\
\text { fund, where their employer is a } \\
\text { participating employer of more then } \\
\text { one fund and where the eligibility } \\
\text { requirements would allow members to } \\
\text { transfer to another fund. }\end{array}$ & No. & $\begin{array}{l}\text { Yes, but not all funds provide for } \\
\text { members to have individual } \\
\text { investment choice. It depends on the } \\
\text { fund's rules. }\end{array}$ \\
\hline
\end{tabular}


OECD DISCUSSION PAPER ON INSURANCE AND PRIVATE PENSIONS

\begin{tabular}{|l|l|l|l|l|}
\hline COUNTRY & PENSION PLAN & $\begin{array}{l}\text { CHOICE OF ADMINISTRATIVE } \\
\text { INSTITUTION/PENSION FUND }\end{array}$ & CHOICE OF PRODUCT & CHOICE OF PORTFOLIO \\
\hline Turkey & $\begin{array}{l}\text { Voluntary personal } \\
\text { pension plan. }\end{array}$ & $\begin{array}{l}\text { Yes, the member can choose the } \\
\text { pension fund company. }\end{array}$ & $\begin{array}{l}\text { Yo. but the choice of the member is } \\
\text { limited to the selection of pension } \\
\text { mutual funds offered in the pension } \\
\text { plan. The member is not allowed to } \\
\text { change the pre-determined asset } \\
\text { composition in the pension mutual } \\
\text { funds. } .^{19} \text {. }\end{array}$ \\
\hline
\end{tabular}

${ }^{19}$ In the case of Turkey, "product" refers to pension mutual fund (PMF), and "portfolio" refers to the composition of pension mutual funds. Currently, no investment vehicle other than PMFs are allowed within the private pension system, so there is no choice of product. 